\title{
Identification guide to the heterobranch sea slugs (Mollusca: Gastropoda) from Bocas del Toro, Panama
}

\author{
Jessica A. Goodheart ${ }^{1,2}$, Ryan A. Ellingson ${ }^{3}$, Xochitl G. Vital ${ }^{4}$, Hilton C. Galvão Filho ${ }^{5}$, Jennifer B. McCarthy ${ }^{6}$, \\ Sabrina M. Medrano ${ }^{6}$, Vishal J. Bhave ${ }^{7}$, Kimberly García-Méndez ${ }^{8}$, Lina M. Jiménez ${ }^{9}$, Gina López ${ }^{10,11}$, \\ Craig A. Hoover ${ }^{6}$, Jaymes D. Awbrey ${ }^{3}$, Jessika M. De Jesus ${ }^{3}$, William Gowacki ${ }^{12}$, Patrick J. Krug $^{3}$ and Ángel Valdé $5^{6^{*}}$
}

\begin{abstract}
Background: The Bocas del Toro Archipelago is located off the Caribbean coast of Panama. Until now, only 19 species of heterobranch sea slugs have been formally reported from this area; this number constitutes a fraction of total diversity in the Caribbean region.

Results: Based on newly conducted fieldwork, we increase the number of recorded heterobranch sea slug species in Bocas del Toro to 82. Descriptive information for each species is provided, including taxonomic and/or ecological notes for most taxa. The collecting effort is also described and compared with that of other field expeditions in the Caribbean and the tropical Eastern Pacific.
\end{abstract}

Conclusions: This increase in known diversity strongly suggests that the distribution of species within the Caribbean is still poorly known and species ranges may need to be modified as more surveys are conducted.

Keywords: Heterobranchia, Nudibranchia, Cephalaspidea, Anaspidea, Sacoglossa, Pleurobranchomorpha

\section{Introduction}

The Bocas del Toro Archipelago is located on the Caribbean coast of Panama, near the Costa Rican border. The major islands of the archipelago include Isla Colón, Bastimentos, Solarte, Cristóbal, Popa and Cayo Aqua. The archipelago has a predominantly wet climate, receiving an average precipitation of $2870 \mathrm{~mm}$ per year (Gordon, 1982) and a maximum of $7000 \mathrm{~mm}$ (Rodríguez et al., 1993). The primary marine ecosystems in the archipelago consist of mangroves (dominated by red mangroves), seagrass beds and coral reef patches (Wysor \& Kooistra, 2003; Lovelock et al., 2004; Collin, 2005).

The Bocas del Toro Research Station, a well-known marine station of the Smithsonian Tropical Research Institute (STRI), is located on Isla Colón. Numerous researchers at this station, both past and present, have utilized the waters surrounding the archipelago for various

\footnotetext{
* Correspondence: aavaldes@cpp.edu

${ }^{6}$ Department of Biological Sciences, California State Polytechnic University,

3801 West Temple Avenue, Pomona, CA 91768, USA

Full list of author information is available at the end of the article
}

studies. However, this research has often been hampered by a lack of accurate and updated identification/field guides. This is particularly problematic for researchers studying heterobranch sea slugs, for which the taxonomy and systematics have changed dramatically in recent years. The only available field guide for Caribbean heterobranch sea slugs (Valdés et al., 2006) is outdated and in need of revision.

Although the Caribbean Sea is inhabited by hundreds of heterobranch sea slug species (Valdés et al., 2006), only 19 species have been formally identified and documented in the Bocas del Toro Archipelago (Collin et al., 2005), representing only a fraction of the total diversity of sea slugs in the Caribbean.

In this paper we present an updated record of the diversity of heterobranch sea slugs in the Bocas del Toro Archipelago, resulting from several research trips to the area and a field course organized by STRI in July and August of 2015. We report new records for Bocas del Toro and provide updated information for previous records 
from the overall area, increasing the total number of observed heterobranch sea slug species in the region to 82 .

\section{Materials and methods}

The STRI course on the taxonomy of sea slugs took place from July $24^{\text {th }}$ to August $5^{\text {th }}, 2015$ in the Bocas del Toro Archipelago, Panama. Collecting effort for this expedition was documented and completed by a total of 16 observers with various levels of experience in searching for sea slugs (the minimum and maximum number of observers at any given time was 7 and 15, respectively). Although the amount of substrata collected was not measured, search time and the number of observers in each location were recorded. Therefore, "collecting effort" refers to the total searching time through direct observations for all observers. The results below represent an estimation of the species found using both direct and indirect methods.

Records from two previous field expeditions in Bocas del Toro are reported here as well, the first occurring in December 2004 and the second in July 2006. Collecting effort during these trips was not quantified, thus is not documented in this paper.

Eleven sites in Bocas de Toro were explored, exclusively during the daytime (Fig. 1). Specimens were documented via: (1) direct observation in the field (mainly snorkeling, but also SCUBA diving), or (2) substrate collection (primarily various species of algae and hydroids). After the substrate was collected and searched, materials were separated into trays with fresh seawater and left to rest overnight to allow for further examination and collection of sea slugs the following day.

Most specimens were identified in the field using the field guide by Valdés et al. (2006) or in the laboratory using primary literature from the Caribbean region. A few problematic specimens were identified based on unpublished sequence data. Some specimens were collected and preserved for further study.

\section{Results}

After approximately 307.5 person-hours of field searching, a total of 82 species belonging to five clades of heterobranch sea slugs were found, some of which have not yet been described (Table 1). The clade Nudibranchia had the highest number of species $(n=40, \sim 49 \%$ of total) and was present in all eleven localities, followed by Sacoglossa ( $n=28, \sim 34 \%$ of total), which was present in all localities but one. In contrast, Pleurobranchomorpha had the lowest number of species $(n=2,<3 \%$ of total) and was found in only three localities (Table 1).

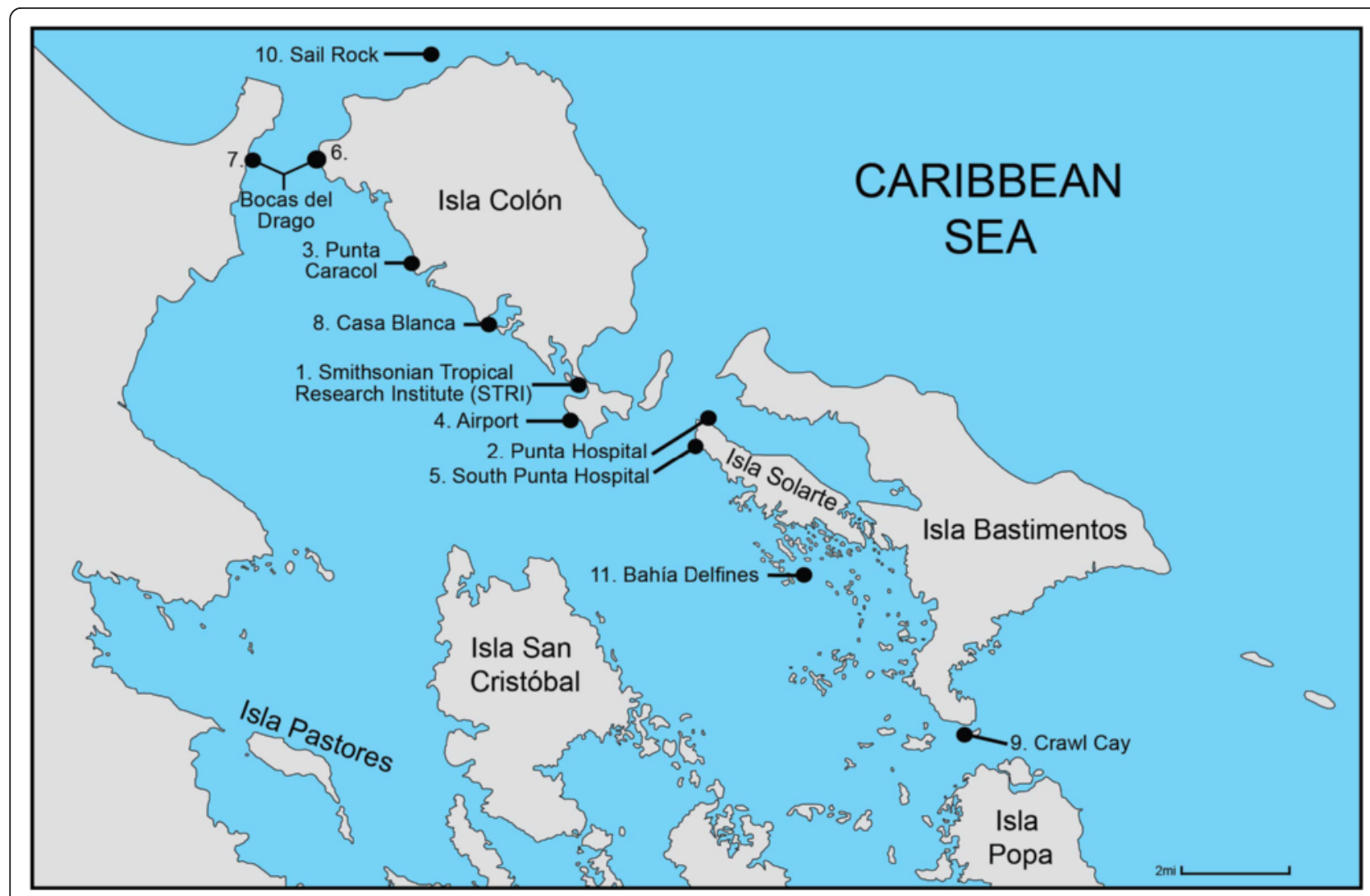

Fig. 1 Map of localities sampled in Bocas del Toro, Panama 
Table 1 Number and proportion of species found per clade in Bocas del Toro, Panama

\begin{tabular}{llcl}
\hline Order & $\begin{array}{l}\text { Number of } \\
\text { species }\end{array}$ & Percentage of total & Localities \\
\hline Cephalaspidea & 6 & 7.3 & $1,8-11$ \\
Anaspidea & 6 & 7.3 & $1,6,10$ \\
Sacoglossa & 28 & 34.1 & $1-10$ \\
Pleurobranchomorpha & 2 & 2.4 & $2,4,9$ \\
Nudibranchia & 40 & 48.8 & $1-11$ \\
\hline
\end{tabular}

The highest number of species $(n=22)$ was found at STRI (locality 1), followed by Crawl Cay (locality 9) and Sail Rock (locality 10), and the lowest overall species number $(n=2)$ was recorded in the Panamanian mainland side of Bocas del Drago (locality 7) (Table 2). All sites had species belonging to the clades Nudibranchia and Sacoglossa, except for Little Cay in Bahía Delfines (locality 11), in which sacoglossans were not found. The average search time and number of nudibranch species found per locality were almost $28 \mathrm{~h}$ and $n=5$, respectively. The locality with the highest collecting effort was STRI (locality 1) and the lowest was the Panamanian mainland side of Bocas del Drago (locality 7) (Table 2), which might explain the highest and lowest number of species found. It is also important to note that locality 7 was the only collecting site located off the Panamanian mainland, which contains numerous rivers and is strongly influenced by terrestrial runoff and turbidity in the water. These factors likely reduced the overall abundance of heterobranch sea slugs and impeded attempts to find them. In Sail Rock (locality 10) all the species were found by indirect methods.

In the systematics section below, summarized descriptions and illustrations are provided for described species as well as for those species previously recognized as distinct in other studies. For most species the habitat information (substrate or food source on which specimens were found) is provided. In cases in which the food source is important for field collection or identification, but the animals were not found in association with specific substrates, this information is provided with references. Several sacoglossan species were kept in captivity and the egg masses obtained and examined; brief descriptions of the egg masses are also included. For some species egg mass information is provided with references meaning that these data were not obtained in the course of this study.

\section{Systematics}

Clade Nudipleura Wägele \& Willan, 2000

Order Pleurobranchomorpha Pelseneer, 1906

Suborder Pleurobranchoidea Gray, 1827

Family Pleurobranchidae Gray, 1827

Genus Pleurobranchus Cuvier, 1804

Pleurobranchus areolatus Mörch, 1863

(Fig. 2a)

\section{Synonyms}

Pleurobranchus crossei Vayssière, 1896; Pleurobranchus atlanticus Abbott, 1949; Pleurobranchus reesi White, 1952; Susania gardineri White, 1952; Pleurobranchus evelinae Thompson, 1977; Pleurobranchus emys Ev. Marcus, 1984.

\section{Description}

Body oval. Rhinophores rolled and fused at the base, with horizontal striations from base to tip. Dorsum with numerous small, polygonal and flat tubercles. Shell internal. Background color ranges from light brown to deep violet, with varying degrees of opaque white pigment on the tubercles. In some cases the opaque white pigment is arranged in a symmetrical pattern across the body. Up to $150 \mathrm{~mm}$ long.

Table 2 Search time and number of species found in each of the 11 sites explored in Bocas del Toro, Panama

\begin{tabular}{|c|c|c|c|c|c|c|c|}
\hline Site & Search time (h) & Nudibranchia & Anaspidea & Pleurobranchomorpha & Cephalaspidea & Sacoglossa & Total \\
\hline 1 & 75.25 & 10 & 3 & 0 & 1 & 8 & 22 \\
\hline 2 & 34.75 & 3 & 0 & 1 & 0 & 5 & 9 \\
\hline 3 & 36 & 3 & 0 & 0 & 0 & 1 & 4 \\
\hline 4 & 25.5 & 7 & 0 & 2 & 0 & 2 & 11 \\
\hline 5 & 18.42 & 1 & 0 & 0 & 0 & 4 & 5 \\
\hline 6 & 21.42 & 6 & 1 & 0 & 0 & 2 & 9 \\
\hline 7 & 2.67 & 1 & 0 & 0 & 0 & 1 & 2 \\
\hline 8 & 22.5 & 3 & 0 & 0 & 1 & 2 & 6 \\
\hline 9 & 44.5 & 13 & 0 & 1 & 1 & 3 & 18 \\
\hline 10 & 4.5 & 9 & 2 & 0 & 2 & 3 & 16 \\
\hline 11 & 22 & 4 & 0 & 0 & 2 & 0 & 6 \\
\hline
\end{tabular}




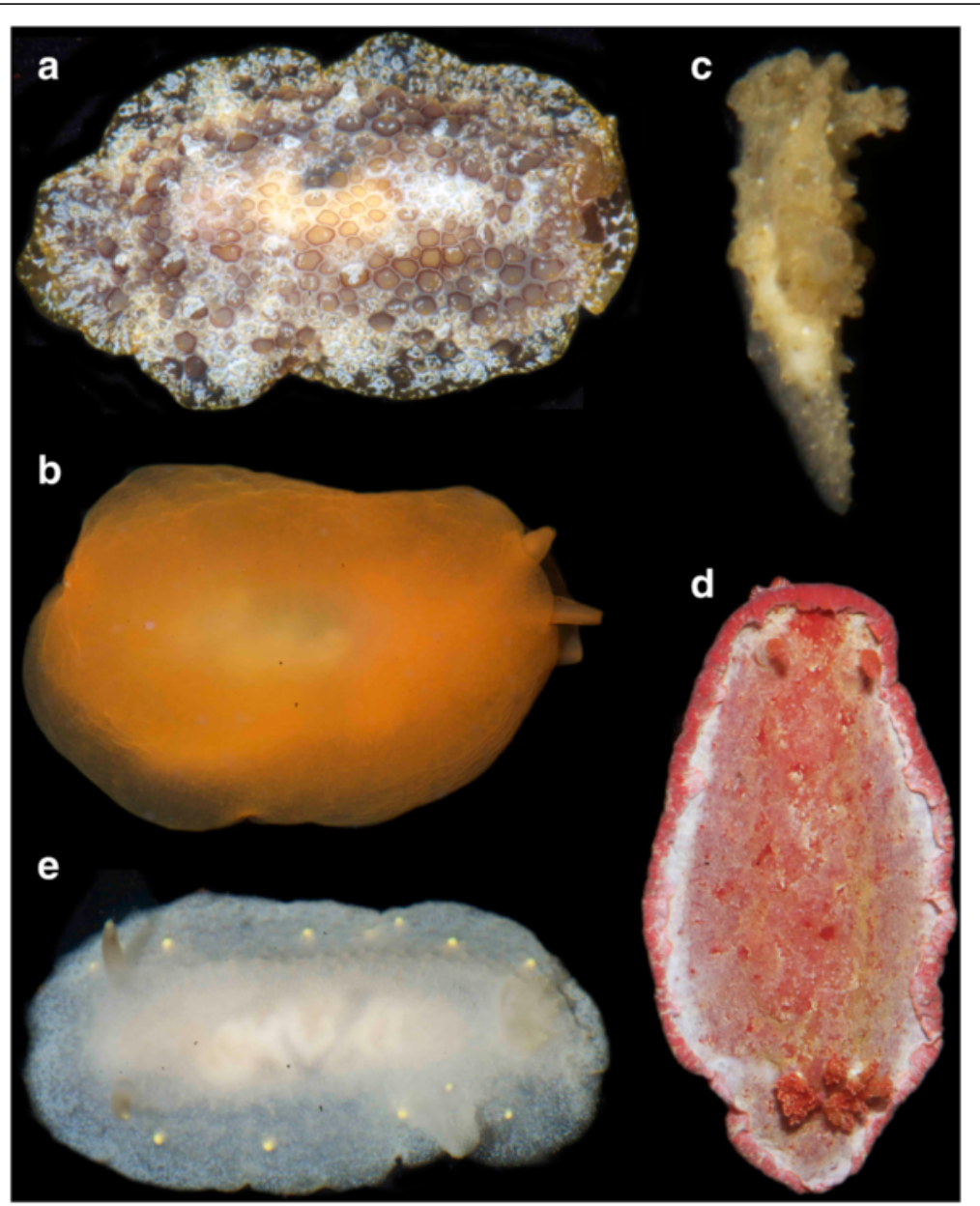

Fig. 2 Nudipleura: Pleurobranchidae, Hexabranchidae, Aegiridae and Cadlinidae. a Pleurobranchus areolatus Mörch, 1863; b Berthellina quadridens (Mörch, 1863); c Aegires ortizi Templado, Luque \& Ortea, 1987; d Hexabranchus morsomus Ev. Marcus \& Er. Marcus, 1962; e Cadlina rumia Er. Marcus, 1955

\section{Distribution}

Mexico, Costa Rica, Venezuela, Brazil, Jamaica, Puerto Rico, St. Thomas, Aruba, St. Maarten/St Martin, Bahamas, Bermuda (Valdés et al., 2006; Goodheart et al., 2015) and Panama (Collin et al., 2005).

\section{Notes}

This species is found under rocks and coral rubble and probably feeds on ascidians (Willan, 1984; Valdés et al., 2006). Although there were believed to be six species of Pleurobranchus in the Caribbean, the other five (Pleurobranchus atlanticus Abbott, 1949, Pleurobranchus evelinae Thompson, 1977, Pleurobranchus crossei Vayssière, 1896, Susania gardineri White, 1952, Pleurobranchus reesi White, 1952 and Pleurobranchus emys Ev. Marcus, 1984) were recently synonymized with $P$. areolatus, based on molecular and morphological evidence (Goodheart et al., 2015).
Genus Berthellina Gardiner, 1936

Berthellina quadridens (Mörch, 1863)

(Fig. 2b)

\section{Description}

Body oval, inflated. Dorsum smooth covering the internal shell, which is located over the anterior portion of the viscera. Anterior end of the body with a large oral veil, rhinophores rolled emerging between the veil and the dorsum. Color yellow to orange, semi-translucent. Up to $25 \mathrm{~mm}$ long.

\section{Distribution}

Mexico, Belize, Colombia, Costa Rica, Panama, Venezuela, Aruba, Curaçao, Haiti, Jamaica, Puerto Rico, Virgin Islands, St. Maarten/St. Martin, St. Lucia, Guadeloupe, Martinique, Barbados, St. Vincent and the Grenadines, Grenada, 
Trinidad and Tobago, Brazil (Valdés et al., 2006; Camacho-García et al., 2014).

\section{Notes}

Possibly feeds on sponges (Willan, 1984) and likely on the corals Orbicella faveolata (Ellis \& Solander, 1786) and Orbicella annularis (Ellis \& Solander, 1786) (see Vermeij, 2010) as well as on anemones (Marcus \& Marcus 1967).

Order Nudibranchia Odhner, 1984

Infraorder Anthobranchia Wägele \& Willan, 2000

Family Aegiridae P. Fischer, 1883

Genus Aegires Lovén, 1844

Aegires ortizi Templado, Luque \& Ortea, 1987

(Fig. 2c)

\section{Description}

Body elongate. Tubercles large, varying from conical to mushroom-shaped, with flat tops in some individuals. Gill leaves forming a semicircle on the posterior portion of the dorsum. Background color usually mottled white, sometimes with noticeable brown spots. Up to $8 \mathrm{~mm}$ long.

\section{Distribution}

Cayman Islands, Bahamas, Venezuela, Cuba (Valdés et al., 2006; Caballer Gutiérrez et al., 2015) and Panama (present study).

\section{Notes}

A single specimen was found on cyanobacteria over coral rubble and sand patches. In the Bahamas this species has been found on algae of the genera Cladophora Kützing, 1843 and Sargassum Agardh, 1820 (see Redfern, 2001).

Family Hexabranchidae Bergh, 1891

Genus Hexabranchus Ehrenberg, 1828

Hexabranchus morsomus Ev. Marcus \& Er. Marcus, 1962

(Fig. 2d)

\section{Description}

Body oval to elongate. Dorsum with small conical tubercles. Rhinophores club shaped. Gill large, composed of several multi-pinnated leaves. Background color reddish with mottled white and yellow patches on the dorsum. Mantle margin usually curled up over small portion of dorsum covering white areas. Up to $400 \mathrm{~mm}$ long.

\section{Distribution}

Honduras, Costa Rica, Venezuela, Aruba, Puerto Rico, Virgin Islands, St. Maarten/St. Martin, St. Lucia, Martinique, Antigua, Grenada, St. Vincent and the Grenadines, Trinidad and Tobago (Valdés et al., 2006) and Panama (Collin et al., 2005).

\section{Notes}

Found under rocks or coral rubble, primarily on living reefs (Valdés et al., 2006). Defensive behavior consists of the unrolling of the mantle margins to expose bright white areas followed by swimming by contracting the body and mantle margin (Collin et al., 2005). Species of the genus Hexabranchus prey on a variety of sponges (McDonald \& Nybakken, 1997).

Family Cadlinidae Bergh, 1891

Genus Cadlina Bergh, 1879

Cadlina rumia Er. Marcus, 1955

(Fig. 2e)

\section{Description}

Body oval, flat, covered with numerous small tubercles. Background color usually translucent white with a few yellow spots (mantle glands). Rhinophores and gill often yellowish brown. Up to $15 \mathrm{~mm}$ long.

\section{Distribution}

Amphiatlantic. Western Atlantic: Florida, Belize, Panama, Venezuela, Bahamas, Dominican Republic, Jamaica, Puerto Rico, Curaçao, St. Maarten/St. Martin, St. Lucia, St. Vincent \& the Grenadines, Grenada, Brazil (Valdés et al., 2006; Caballer Gutiérrez et al., 2015) and Panama (Collin et al., 2005).

\section{Notes}

This is the only species of Cadlina in the tropical western Atlantic (Edmunds, 1981; Valdés et al., 2006, GarcíaGarcía et al., 2008). The genus Cadlina was recently transferred from the Chromodorididae to the Cadlinidae (Johnson \& Gosliner, 2012). In our study C. rumia was found under rocks and on various sponges. This species feeds on several types of sponges from different orders (including spiculate and non-spiculate species), exhibiting a not specialized diet preference among the spongivorous dorid nudibranchs (Belmonte et al., 2015).

Family Chromodorididae Bergh, 1891

Genus Tyrinna Bergh, 1898

Tyrinna evelinae (Er. Marcus, 1958)

(Fig. 3a)

\section{Synonyms}

Cadlina burnayi Ortea, 1988.

\section{Description}

Body oval to elongate. Background color usually translucent white with a number of orange spots. Mantle margin edged by an opaque white line and white mantle glands with orange tips. Rhinophores and branchial leaves translucent white with opaque white tips. Up to $30 \mathrm{~mm}$ long. 


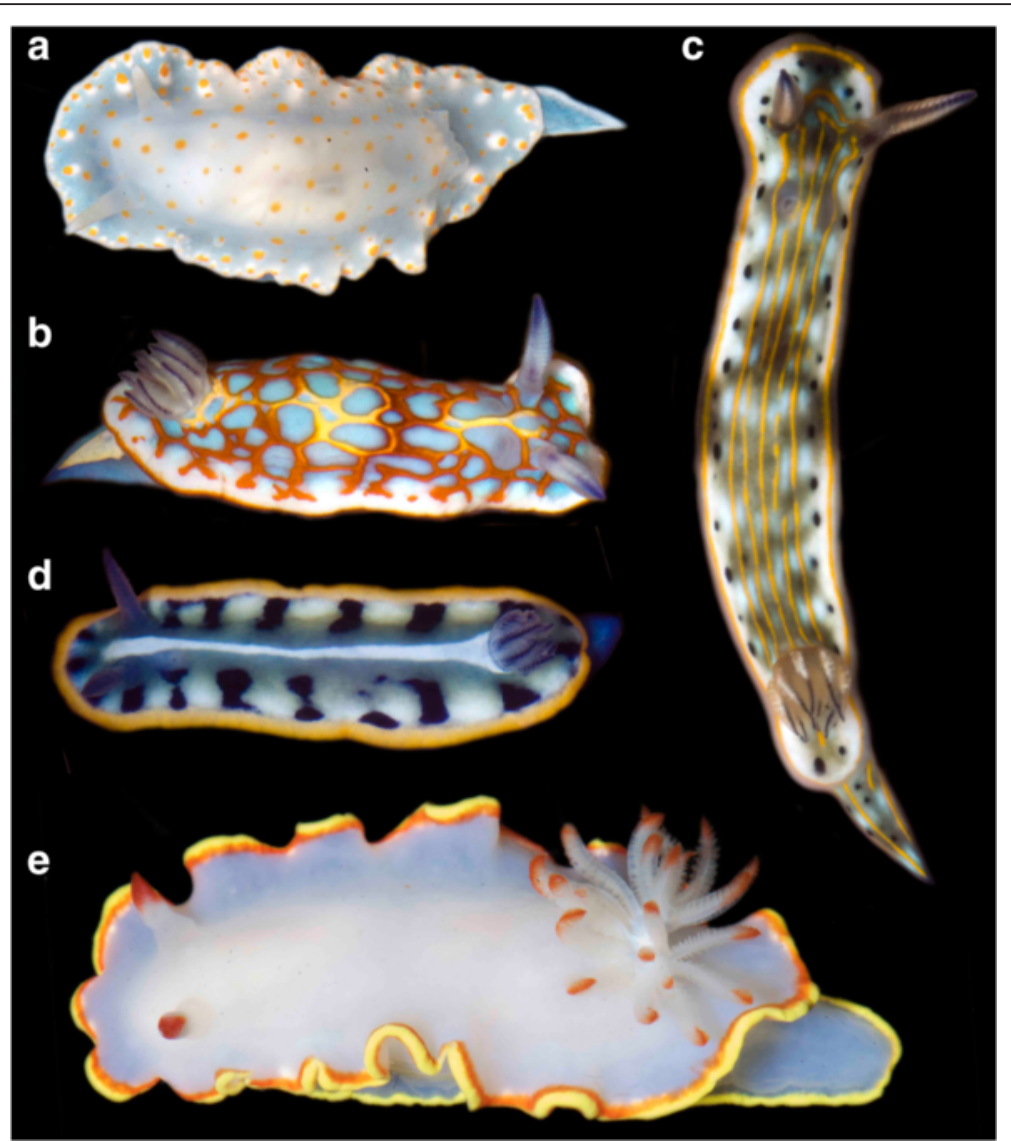

Fig. 3 Nudipleura: Chromodorididae. a Tyrinna evelinae (Er. Marcus, 1958); b Felimida clenchi (Russell, 1935); c Felimare fregona (Ortea \& Caballer in Ortea et al., 2013); d Felimare kempfi (Ev. Marcus, 1971); e Doriprismatica sedna (Ev. Marcus \& Er. Marcus, 1967)

\section{Distribution}

Eastern Atlantic, Eastern Pacific, and Western Atlantic: Costa Rica, Venezuela, Jamaica, Puerto Rico, Dominican Republic, Brazil (Valdés et al., 2006; Caballer Gutiérrez et al., 2015) and Panama (present study).

\section{Notes}

Found under rocks and on various sponges in this study. Belmonte et al. (2015) found that Tyrinna evelinae in Brazil feeds primarily on dysideid sponges, but also upon an unidentified chalinid species of the order Haplosclerida. This species has planktotrophic development. Caribbean populations are morphologically indistinguishable from Eastern Pacific and Eastern Atlantic populations (Valdés et al., 2006).

Genus Felimida Ev. Marcus, 1971

Felimida clenchi (Russell, 1935)

(Fig. 3b)

\section{Description}

Body oval. Dorsum smooth. Background color pale blue with a dense pattern of red covering the dorsum, but leaving small circular uncovered areas. The red becomes yellow near the rhinophores and gill. Mantle margin with a submarginal white band edged with a red line. Rhinophores and gill white with purple rachises. Up to $30 \mathrm{~mm}$ long.

\section{Distribution}

Florida, Costa Rica, Panama, Colombia, Venezuela, Bermuda, Cayman Islands, Jamaica, Curaçao, St. Lucia, St. Vincent and the Grenadines (Valdés et al., 2006; Caballer Gutiérrez et al., 2015).

\section{Notes}

Found under rocks or on sponges in this study. Originally a member of the genus Chromodoris Alder \& Hancock, 1855, this species was recently transferred to Felimida by Johnson \& Gosliner (2012). This species is part of a complex that comprises Felimida binza (Ev. Marcus \& Er. Marcus, 1963), Felimida britoi (Ortea \& Pérez, 1983) and Felimida neona (Er. Marcus, 1955). All these species share a similar reticular pattern of yellow and red pigment and morphology (Ortea et al., 1994; Valdés et al., 2011; Camacho-García et al., 2014). 
Felimare fregona (Ortea \& Caballer in Ortea et al., 2013) (Fig. 3c)

\section{Description}

Body elongate, narrow, with the posterior portion of foot extending beyond the mantle margin. Background color white with irregular shades of pale blue and gray. Dorsum with three longitudinal yellow lines. Mantle margin edged by an opaque white line with a narrow submarginal band of yellow and a series of black circular spots. Rhinophores white with a purple longitudinal line up from the base. Up to $40 \mathrm{~mm}$ long.

\section{Distribution}

Venezuela, Puerto Rico, Virgin Islands, Curaçao (Valdés et al., 2006), Guadeloupe (Ortea et al., 2013), and Panama (present study).

\section{Notes}

Feeds on a blue sponge (Valdés et al., 2006). Recently described by Ortea \& Caballer in Ortea et al. (2013) from Guadeloupe. Appears to be the same morphotype illustrated by Valdés et al. (2006) as Hypselodoris sp. 3.

Genus Felimare Ev. Marcus \& Er. Marcus, 1967

Felimare kempfi (Ev. Marcus, 1971)

(Fig. 3d)

\section{Description}

Body elongate, narrow, with the posterior portion of foot extending slightly beyond the mantle margin. Background color bright blue with a thick yellow line around the mantle margin. A central white line and a series of large black and white spots extend down the dorsum. Rhinophores and gills blue, branchial leaves with black rachises. Up to $20 \mathrm{~mm}$ long.

\section{Distribution}

Florida, Mexico, Costa Rica, Venezuela, Brazil, Puerto Rico (Valdés et al., 2006; Caballer Gutiérrez et al., 2015) and Panama (Collin et al., 2005)

\section{Notes}

This species has previously been placed in the genera Chromodoris Alder \& Hancock, 1855 (see Collin et al., 2005) and Mexichromis Bertsch, 1977. It was recently transferred to Felimare by Johnson \& Gosliner (2012).

Genus Doriprismatica d'Orbigny, 1839

Doriprismatica sedna (Ev. Marcus \& Er. Marcus, 1967)

(Fig. 3e)

\section{Synonyms}

Chromodoris fayae Lance, 1968.

\section{Description}

Body oval. Mantle margin ruffled. Background color white with two colored bands (inner red and outer yellow) bordering the foot and mantle. Upper half of the rhinophoral clubs and tips of the branchial leaves of the gill red. Up to $65 \mathrm{~mm}$ long.

\section{Distribution}

Eastern Pacific: from the Gulf of California to the Galapagos Islands (Bertsch, 1988) and Western Atlantic: Florida, Belize, Bahamas (Valdés et al., 2006) and Panama (present study).

\section{Notes}

Found on mangrove roots covered with sponges in this study. The diet of Doriprismatica sedna was studied by Padilla-Verdín et al. (2010) on the Pacific coast of Mexico. By examining the stomach content and feces, they found that this species feeds exclusively on spiculated sponges and exhibits a variable diet, which includes 16 different species. Originally described from the Eastern Pacific, records from the Caribbean are considered the result of a recent introduction, presumably human-induced. This species has previously been placed in the genus Glossodoris Ehrenberg, 1831 (see Valdés et al., 2006), but was recently transferred to Doriprismatica by Johnson \& Gosliner (2012).

Family Discodorididae Bergh, 1891

Genus Discodoris Bergh, 1877

Discodoris branneri MacFarland, 1909

(Fig. 4a-b)

\section{Synonyms}

Discodoris evelinae Er. Marcus, 1955; Discodoris hedgpethi Ev. Marcus \& Er. Marcus, 1960.

\section{Description}

Body oval, moderately rigid. Dorsum covered by numerous conical tubercles. Background color variable, from cream to purplish brown, sometimes with black or white patches and spots. Rhinophores and gill usually the same color as the dorsum with white tips. Up to $110 \mathrm{~mm}$ long.

\section{Distribution}

Florida, Texas, Costa Rica, Honduras, Panama, Colombia, Venezuela, Bahamas, Cayman Islands, Puerto Rico, Jamaica, Barbados, Martinique, St. Lucia, Guadeloupe, St. Vincent and the Grenadines, Brazil (Valdés et al., 2006).

\section{Notes}

Found under rocks in this study. Members of this family feed on sponges. When disturbed, this species autotomizes parts of the mantle (Valdés et al., 2006). This species previously identified as Discodoris evelinae Er. Marcus 1955, 


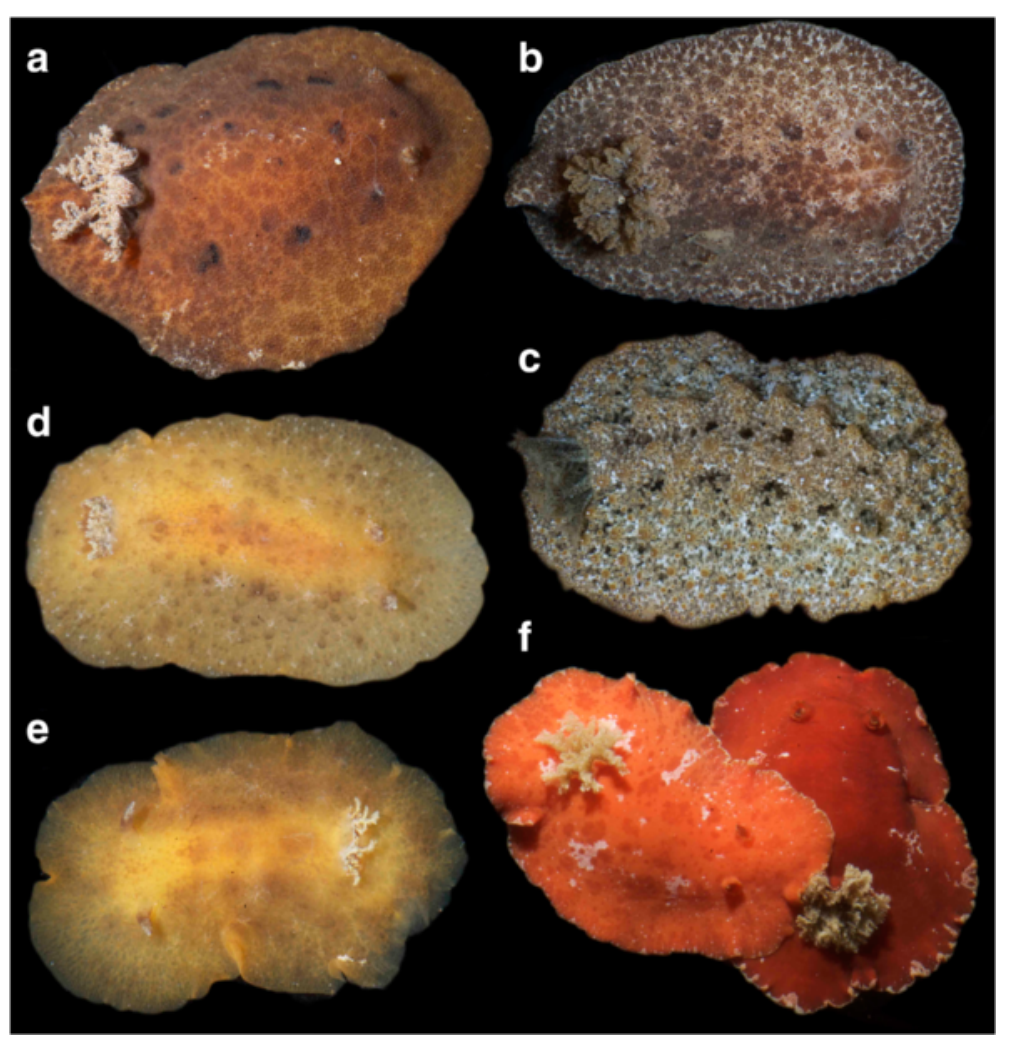

Fig. 4 Nudipleura: Discodorididae. a-b Discodoris branneri MacFarland, 1909; c Sclerodoris prea (Ev. Marcus \& Er. Marcus, 1967); d Geitodoris cf. planata (Alder \& Hancock, 1846); e Geitodoris immunda Bergh, 1894; f Platydoris angustipes (Mörch, 1863)

but is now accepted as Discodoris branneri (see Alvim \& Pimenta, 2013).

\section{Genus Sclerodoris Eliot, 1904}

Sclerodoris prea (Ev. Marcus \& Er. Marcus, 1967)

(Fig. 4c)

\section{Description}

Body oval, mantle rigid. Dorsum covered with numerous caryophyllidia. Larger tubercles arranged in two rows along the visceral hump, with a longitudinal depression in the center. Rhinophores elongate, gill composed of multipinnate branchial leaves. Background color creambrown with numerous dark brown spots. Black patches present along the center of the visceral hump. Rhinophores cream with dark spots and gill gray with opaque white spots. Up to $40 \mathrm{~mm}$ long.

\section{Distribution}

Florida, Venezuela, Bahamas, Jamaica and Barbados (Valdés et al., 2006; Caballer Gutiérrez et al., 2015) and Panama (present study).

\section{Notes}

Found under rocks in this study. This species probably feeds on sponges.

Geitodoris cf. planata (Alder \& Hancock, 1846)

(Fig. 4d)

\section{Synonyms}

Doris testudinaria Risso, 1826; Doris complanata Verrill, 1880.

\section{Description}

Body oval, mantle rigid. Dorsum covered by rounded, stalked tubercles. Background color grayish-brown with some dark brown irregular patches. The color fades and becomes more translucent towards the mantle margin. Larger tubercles surrounded with opaque white pigment. Rhinophores and gill usually the same color as the dorsum with white tips. Up to $65 \mathrm{~mm}$ long.

\section{Distribution}

Mediterranean Sea, North Atlantic Ocean, North Sea (Whittaker, 2013); Western Atlantic: New Jersey, St. Lucia (Valdés et al., 2006) and Panama (present study). 


\section{Notes}

Found in coral rubble in a predominately sea grass habitat in this study. Feeds on sponges (McDonald \& Nybakken, 1997). Originally described from Europe, Caribbean populations are morphologically similar but almost certainly distinct. Alvim \& Pimenta (2013) regarded Caribbean animals as Geitodoris pusae (Er. Marcus, 1955), but no molecular studies have been conducted to compare animals from both sides of the Atlantic Ocean. Further research is necessary to clarify the status of this species.

Genus Geitodoris Bergh, 1891

Geitodoris immunda Bergh, 1894

(Fig. 4e)

\section{Description}

Body oval, mantle moderately rigid. Dorsum with a complex network of low ridges covering the entire surface, with some conical tubercles at the intersections. Branchial sheaths with characteristic wavy edges. Background color grayish-brown with numerous opaque white dots and some darker brown areas. Rhinophores and gill brown with white tips. Up to $43 \mathrm{~mm}$ long.

\section{Distribution}

Gulf of Mexico, Costa Rica, Venezuela, Brazil (Valdés et al., 2006, Moretzsohn et al., 2011) and Panama (present study).

\section{Notes}

Found under coral rubble in a reef habitat in this study. This species as well as the preceding one are similar to Geitodoris pusae (Er. Marcus, 1955), redescribed by Alvim \& Pimenta (2013). Further review is necessary to clarify the taxonomic status of these taxa.

Genus Platydoris Bergh, 1877

Platydoris angustipes (Mörch, 1863)

(Fig. 4f)

\section{Synonyms}

Platydoris alaleta Bergh, 1877; Platydoris rubra White, 1952.

\section{Description}

Body oval, mantle rigid. Dorsum flattened, covered with caryophyllidia. Background color ranges from reddishbrown to red or orange with scattered white specks often clustered in 3-4 dense groups. Mantle margin often darker or lighter than the rest of the mantle with proportionally more white patches. Rhinophores dark brown with cylindrical apex. Gill translucent strawcolored often with numerous opaque white spots. Up to $150 \mathrm{~mm}$ long.

\section{Distribution}

Central American mainland, from Florida to Panama, also Greater Antilles, Cayman Islands, Lesser Antilles, Turks and Caicos, and Brazil (Valdés et al., 2006; Camacho-García et al., 2014; Caballer Gutiérrez et al., 2015).

\section{Notes}

Found under rocks in this study. This species possibly has lecithotrophic development. Additional information and descriptions provided by Alvim \& Pimenta (2013).

Genus Diaulula Bergh, 1878

Diaulula phoca (Ev. Marcus \& Er. Marcus, 1967)

(Fig. 5a)

\section{Description}

Body oval, mantle rigid. Dorsum covered with small caryophyllidia. Body, rhinophores, and gill dark purplish brown with numerous small opaque white dots. Up to $50 \mathrm{~mm}$ long.

\section{Distribution}

Florida, Honduras, Costa Rica, Brazil (Valdés et al., 2006, García-García et al., 2008) and Panama (present study).

\section{Notes}

Feeds on sponges (Marcus \& Marcus 1967). Originally named Discodoris phoca Marcus \& Marcus 1967 it is considered a member of Diaulula because of the presence of caryophyllidia.

Genus Jorunna Bergh, 1876

Jorunna cf. spazzola (Er. Marcus, 1955)

(Fig. 5b-c)

\section{Synonyms}

Discodoris mortenseni Ev. Marcus \& Er. Marcus, 1963.

\section{Description}

Body oval, mantle rigid. Dorsum flattened, covered with small caryophyllidia. Branchial leaves very short. Background color translucent gray with a few darker gray or brown patches over the dorsum. Mantle margin surrounded by small opaque white glands. Rhinophores and gill the same color as the rest of the body. Up to $18 \mathrm{~mm}$ long.

\section{Distribution}

Florida, Honduras, Costa Rica, Venezuela, Cuba, Curaçao, Barbados, Virgin Islands, Turks and Caicos, Brazil (Valdés et al., 2006; Camacho-García et al., 2014; Caballer Gutiérrez et al., 2015) and Panama (present study). 


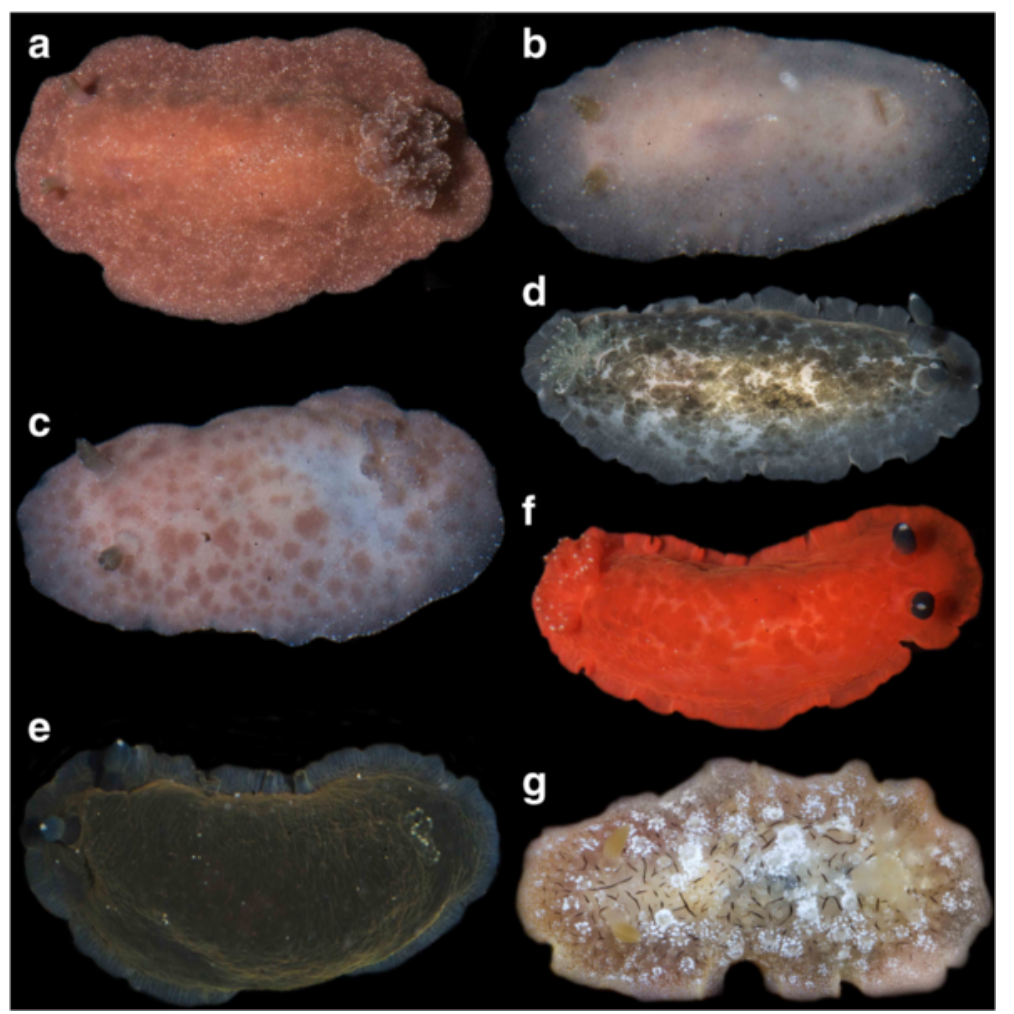

Fig. 5 Nudipleura: Discodorididae and Dendrodorididae. a Diaulula phoca (Ev. Marcus \& Er. Marcus, 1967); b-c Jorunna cf. spazzola (Er. Marcus, 1955); d-f Dendrodoris krebsii (Mörch, 1863) g Doriopsilla nigrolineata Meyer, 1977

\section{Notes}

Found under rocks in this study. Known to feed on sponges of the order Haplosclerida (Belmonte et al., 2015) on which it is well camouflaged. This species is able to quickly change colors as a response to unknown environmental cues (Valdés et al., 2006). Camacho-García et al. (2014) suggested Caribbean animals identified as Jorunna spazzola could constitute a distinct species, because they display external differences with the original description from southern Brazil.

Family Dendrodorididae O’Donoghue, 1924

Genus Dendrodoris Ehrenberg, 1831

Dendrodoris krebsii (Mörch, 1863)

(Fig. 5d-f)

\section{Description}

Body oval to elongate, dorsum soft, lacking tubercles. Background color extremely variable, white, black, orange, red or light green, with or without spots of red, black, gray or white. Rhinophores and gill usually the same color as the rest of the body with white tips. Up to $150 \mathrm{~mm}$ long.

\section{Distribution}

North and south American mainland from Georgia to Brazil, Bahamas, Cuba, Cayman Islands, Jamaica,
Dominican Republic, Virgin Islands, St. Martin, Antigua, Guadeloupe, Martinique, St. Lucia, St. Vincent and the Grenadines, Barbados, Aruba, Curaçao, Bonaire, Grenada (Valdés et al., 2006; Camacho-García et al., 2014).

\section{Notes}

Found under coral rubble or rocks in this study. This is one of the most common species of Nudibranchia in the Caribbean. Members of this family are suctorial sponge feeders. Belmonte et al. (2015) recorded active feeding of Dendrodoris krebsii upon a haplosclerid sponge.

Genus Doriopsilla Bergh, 1880

Doriopsilla nigrolineata Meyer, 1977

(Fig. 5g)

\section{Synonyms}

Doriopsilla areolata nigrolineata Meyer, 1977.

\section{Description}

Body oval to elongate. Dorsum rigid, covered with rounded tubercles. Background color translucent white to orange, with a series of irregular black lines over the entire dorsum. Bases of tubercles densely spotted with white, rhinophores and gill yellow. Up to $30 \mathrm{~mm}$ long. 


\section{Distribution}

Panama, Honduras (Valdés et al., 2006).

\section{Notes}

Found in 3-6 m of water. Previously considered a subspecies of Doriopsilla areolata Bergh, 1880 by Valdés \& Ortea (1997), but Valdés \& Hamann (2008) confirmed that it is a distinct species.

Infraorder Cladobranchia Willan \& Morton, 1984

Family Tritoniidae Lamarck, 1801

Genus Tritonia Cuvier, 1798

Tritonia hamnerorum Gosliner \& Ghiselin, 1987

(Fig. 6a)

\section{Description}

Body elongate and narrow. Rhinophoral sheaths elevated with an irregular edge. Cerata short and branched. Edge of the oral veil with relatively long appendages, rhinophores long, branched. Background color translucent gray with a series of irregular, longitudinal, thin white lines that run along the length of the dorsum. Up to $15 \mathrm{~mm}$ long.

\section{Distribution}

Florida, Mexico, Belize, Bahamas, Cayman Islands (Valdés et al., 2006) and Panama (present study).

\section{Notes}

Found on gorgonian sea fans in dense aggregations in this study. This species reportedly feeds on the octocorals Gorgonia ventalina Linnaeus, 1758 and Gorgonia flabellum Linnaeus, 1758. It sequesters chemicals from the sea fans and stores them for its own defense (Cronin et al., 1995).

Tritonia bayeri Ev. Marcus \& Er. Marcus, 1967

(Fig. 6b)

\section{Synonyms}

Tritonia bayeri misa Ev. Marcus \& Er. Marcus, 1967.

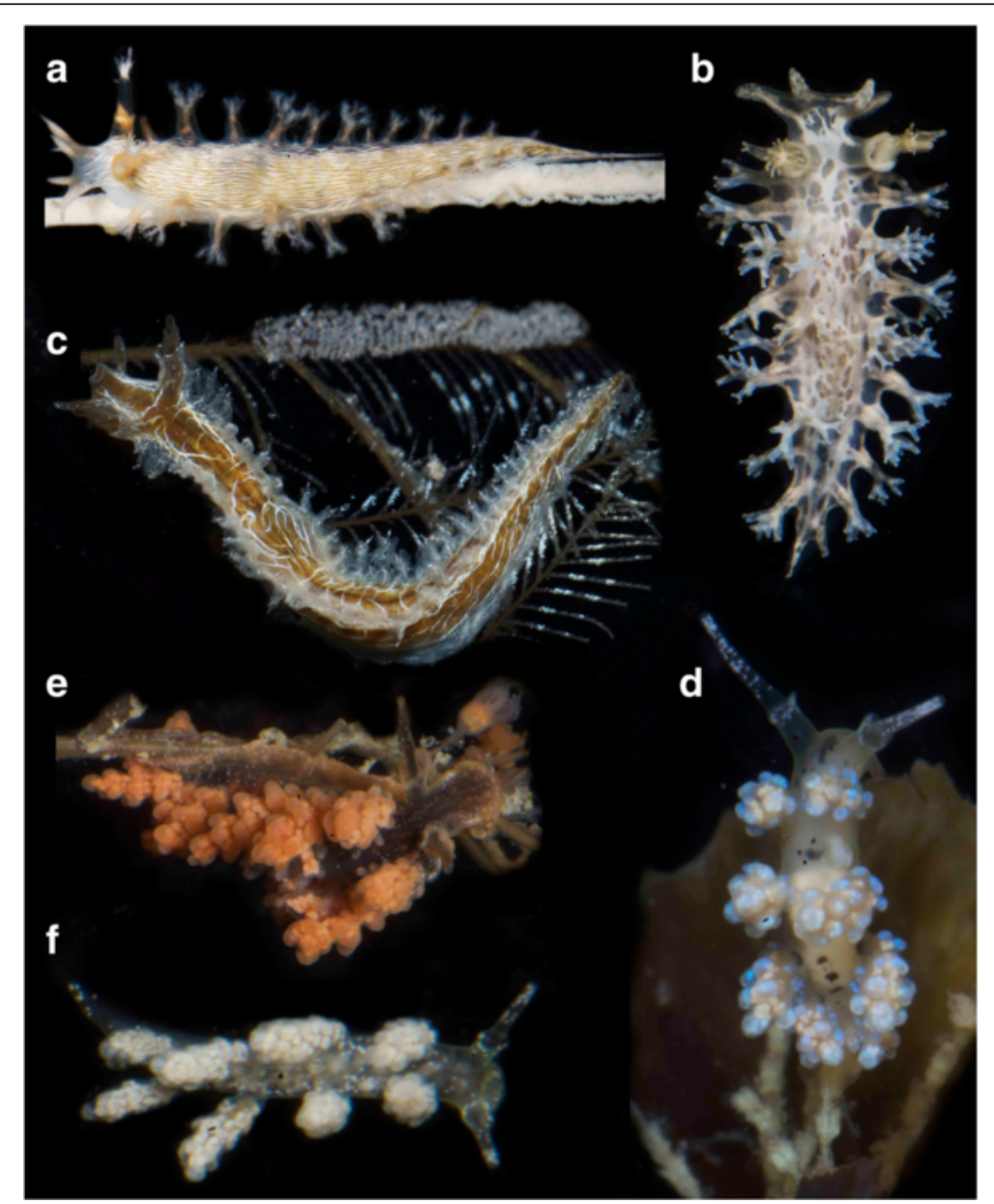

Fig. 6 Nudipleura: Tritoniidae, Lomanotidae and Dotidae. a Tritonia hamnerorum Gosliner \& Ghiselin, 1987 on substrate with egg mass; b Tritonia bayeri Ev. Marcus \& Er. Marcus, 1967. c Lomanotus vermiformis Eliot, 1908, on substrate with egg mass; d Doto escatllari Ortea, Moro \& Espinosa, 1998, on substrate; e Doto chica Ev. Marcus \& Er. Marcus, 1960, on substrate; f Doto cf. wildei Er. Marcus \& Ev. Marcus, 1970 


\section{Description}

Body elongate and narrow. Rhinophoral sheaths elevated with an irregular edge. Cerata relatively short and branched. Edge of the oral veil with relatively long appendages, rhinophores long, branched. Background color translucent gray with a distinctive reticulate network of opaque white across the dorsum. Up to $11 \mathrm{~mm}$ long.

\section{Distribution}

Georgia, Florida, Belize, Honduras, Cayman Islands, Virgin Islands, Guadaloupe, Barbados (Valdés et al., 2006) and Panama (present study).

\section{Notes}

Found on gorgonians and coral rubble in this study. Inhabits reefs down to $77 \mathrm{~m}$ depth. This species feeds on the octocorals Briareum asbestinum (Pallas, 1766), Leptogorgia virgulata (Lamarck, 1815) and Pseudopterogorgia sp. (McDonald \& Nybakken, 1999).

Family Lomanotidae Bergh, 1890

Genus Lomanotus Vérany, 1844

Lomanotus vermiformis Eliot, 1908

(Fig. 6c)

\section{Synonyms}

Lomanotus stauberi Clark \& Goetzfried, 1976.

\section{Description}

Body very elongate and narrow. Rhinophoral sheaths with papillae and elevated to cover three quarters of the rhinophores. Cerata very short and pointed. Background color brown with dark brown spots and opaque yellow lines. Opaque white reticulations also present across the body. Up to $40 \mathrm{~mm}$ long.

\section{Distribution}

Circumtropical. Western Atlantic: Florida, Bahamas (Valdés et al., 2006) and Panama (Collin et al., 2005).

\section{Notes}

This species feeds on hydroids of the genus Macrorhynchia Kirchenpauer, 1872 (McDonald \& Nybakken, 1999). In this study was found feeding on an unidentified species of hydroid (illustrated), on which it is extremely cryptic. This species can swim with lateral flexions of the body when disturbed (Valdés et al., 2006).

Family Dotidae Gray, 1853

Genus Doto Oken, 1815

Doto escatllari Ortea, Moro \& Espinosa, 1998

(Fig. 6d)

\section{Description}

Body short and narrow. Rhinophores smooth. Rhinophoral sheaths with small frontal extensions. Cerata large with rounded tubercles; apical tubercles much larger than the rest. Background color translucent gray with a series of dark brown spots on the dorsum. Cerata with dark brown branches of the digestive gland and bluish tubercles, rhinophores with opaque white dots. Up to $5 \mathrm{~mm}$ long.

\section{Distribution}

Costa Rica, Barbados (Valdés et al., 2006) and Panama (present study).

Notes

Found on hydroids in this study.

Doto chica Ev. Marcus \& Er. Marcus, 1960

(Fig. 6e)

Synonyms

Doto fragilis umia Ev. Marcus \& Er. Marcus, 1969.

\section{Description}

Body narrow and elongate. Rhinophores smooth, rhinophoral sheaths with small posterior extensions. Cerata large, with rounded tubercles; apical tubercles much larger than the rest. Background color translucent gray with a dense series of dark brown spots and a less dense set of opaque white spots on the dorsum. Cerata with orange extensions of the digestive gland. Up to $5 \mathrm{~mm}$ long.

\section{Distribution}

Florida, Mexico, Costa Rica, Venezuela, Puerto Rico, Curaçao, Cuba, Brazil (Valdés et al. 2006; García-García et al., 2008; Crescini et al., 2013) and Panama (present study).

\section{Notes}

Found on hydroids in this study. Known to feed on hydroids of the genus Eudendrium Ehrenberg, 1834 (Ev. Marcus, 1972).

Doto cf. wildei Er. Marcus \& Ev. Marcus, 1970

(Fig. 6f)

\section{Synonyms}

Doto caramella wildei Er. Marcus \& Ev. Marcus, 1970.

\section{Description}

Body narrow and elongate. Rhinophores smooth with tight rhinophoral sheaths. Cerata with rounded tubercles; apical tubercles much larger than the rest. Cerata spaced out along the dorsum. Background color translucent gray with a series of opaque white spots on the dorsum. Cerata 
with cream or white extensions of the digestive gland. Up to $4 \mathrm{~mm}$ long.

\section{Distribution}

Curaçao (Valdés et al., 2006) and Panama (present study).

\section{Notes}

Found on hydroids. The identification of this specimen is uncertain; it looks most similar to Doto wildei but lacks pseudogills on the cerata. The systematics of Doto in the Caribbean region is in need of major revision and until the taxonomy is clarified many species identifications remain tentative.

Family Flabellinidae Bergh, 1889

Genus Flabellina Gray, 1833

Flabellina engeli Ev. Marcus \& Er. Marcus, 1968

(Fig. 7a)

\section{Description}

Body elongate, narrowing posteriorly. Rhinophores lamellate, club-shaped, oral tentacles long. Cerata arranged into clusters in two rows along the dorsum. Background color translucent gray with thick white or yellow patches running between the cerata clusters, on the margin of the dorsum. A submarginal row of opaque white spots present along the sides of the body. Three white or yellow patches on the head. Oral tentacles translucent, white at the tips; rhinophores with white bands. Cerata translucent with a brown or orange band about a third of the way down from the tip. Up to $25 \mathrm{~mm}$ long.

\section{Distribution}

Florida, Costa Rica, Colombia, Venezuela, Barbados, Cuba, Puerto Rico, Curaçao, St. Lucia, Martinique, Granada, Brazil (Valdés et al., 2006; García-García et al., 2008; Caballer Gutiérrez et al., 2015) and Panama (present study).

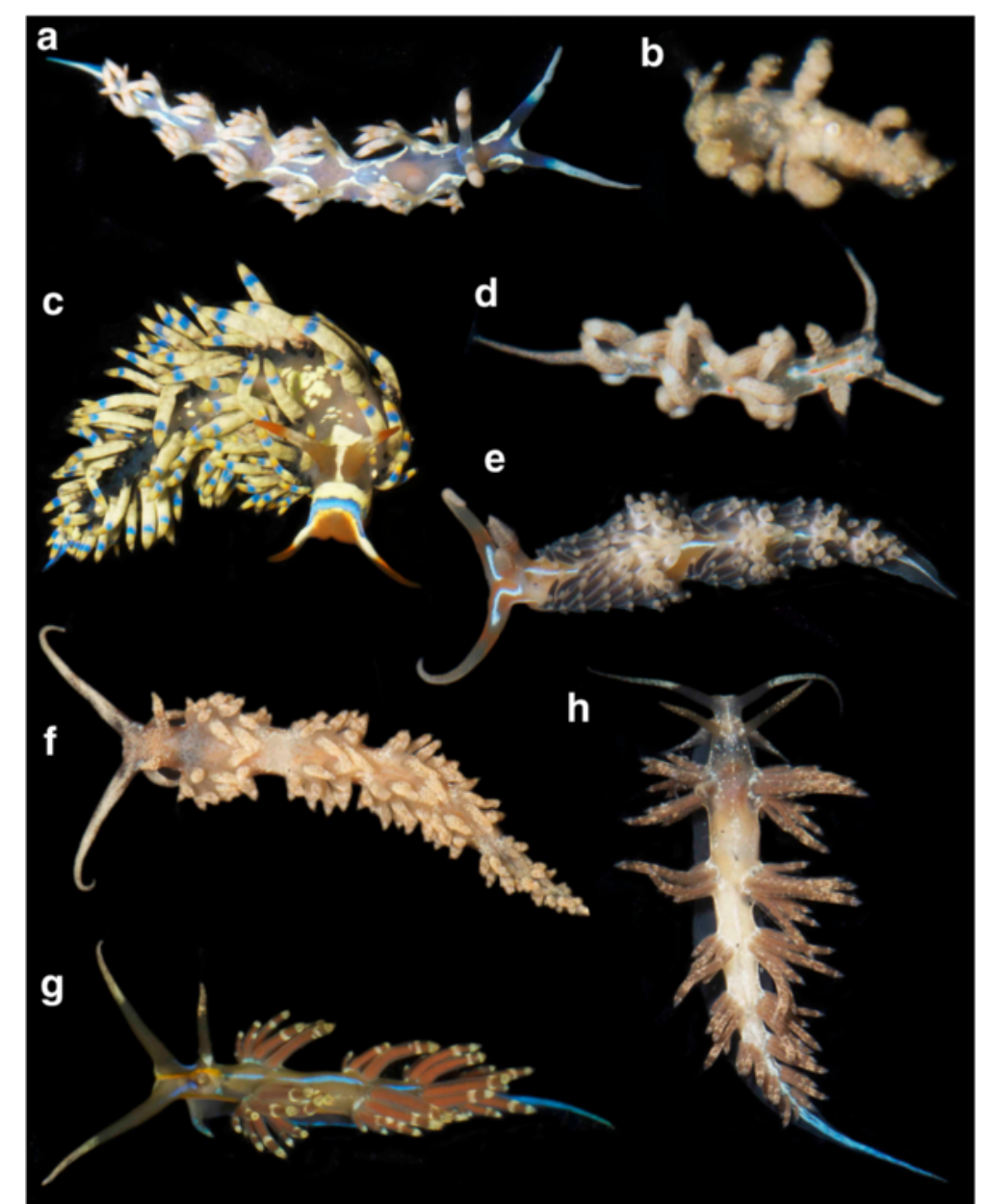

Fig. 7 Nudipleura: Flabellinidae, Eubranchidae, Tergipedidae, and Facelinidae. a Flabellina engeli Ev. Marcus \& Er. Marcus, 1968; b Eubranchus conicla (Er. Marcus, 1958); c Cuthona cf. caerulea (Montagu, 1804); d Nanuca sebastiani Er. Marcus, 1957; e Phidiana lynceus Bergh, 1867; f Palisa papillata Edmunds, 1964; $\mathbf{g}$ Dondice occidentalis (Engel, 1925); h Dondice parguerensis Brandon \& Cutress, 1985 
Notes

One specimen found on a living blade of sea grass in $1 \mathrm{~m}$ of water.

Family Eubranchidae

Genus Eubranchus Forbes, 1838

Eubranchus conicla (Er. Marcus, 1958)

(Fig. 7b)

\section{Synonyms}

Eubranchus convenientis Ortea \& Caballer, 2002.

\section{Description}

Body elongate. Rhinophores smooth, oral tentacles short. Cerata tuberculate, few in number, arranged in two simple rows. Background color translucent gray or brown with numerous white dots. Rhinophores and oral tentacles sometimes ringed with brown. Cerata white, sometimes with brown or green spots. Up to $4 \mathrm{~mm}$ long.

\section{Distribution}

Florida, Honduras, Costa Rica, Venezuela, Jamaica, Barbados, Tobago, Brazil (Valdés et al., 2006; Caballer Gutiérrez et al., 2015) and Panama (present study).

\section{Notes}

Found on Sargassum in less than $3 \mathrm{~m}$ of water.

Family Tergipedidae Bergh, 1889

Genus Cuthona Alder \& Hancock, 1855

Cuthona cf. caerulea (Montagu, 1804)

(Fig. 7c)

\section{Synonyms}

Eolidia bassi Vérany, 1846; Eolis glotensis Alder \& Hancock, 1846; Eolis deaurata Dalyell, 1853; Eolis molios Herdman, 1881.

\section{Description}

Body elongate. Rhinophores smooth, oral tentacles relatively short. Cerata numerous on both sides of the dorsum with a small empty space down the middle of the dorsum. Background color translucent gray with a bright blue patch, and sometimes a yellow patch, on the head. Oral tentacles yellow at the base, orange at the tips. Rhinophores with a translucent base, a central white or yellow area and orange-brown tips. Cerata translucent white, gray or yellow, with a blue band followed by a bright yellow band near the apex. Up to $25 \mathrm{~mm}$ long.

\section{Distribution}

Possibly amphiatlantic. Western Atlantic: Florida to Brazil (Valdés et al., 2006) including Panama (present study).

\section{Notes}

The animals here illustrated are tentatively identified as the European species Cuthona caerulea, but the coloration of the head, with a conspicuous blue patch, is different; they probably constitute an undescribed species. Found on hydroids in this study. This species has been recorded feeding upon hydroids of several different genera (McDonald \& Nybakken, 1999).

Family Facelinidae Bergh, 1889

Genus Nanuca Er. Marcus, 1957

Nanuca sebastiani Er. Marcus, 1957

(Fig. 7d)

\section{Description}

Body elongate. Rhinophores annulate; oral tentacles long. Cerata arranged in two rows of clusters (with 3-5 cerata each) on the dorsum. Background color translucent green with numerous opaque white spots and a series of areas with blue and/or white with orange spots forming a crosslike pattern. Cerata with longitudinal opaque white lines with a white, narrow tip. Up to $12 \mathrm{~mm}$ long.

\section{Distribution}

Mexico, Costa Rica, Venezuela, Curaçao, Bonaire, Martinique, Cuba, Cayman Islands, Virgin Islands, Barbados, Bermuda, Brazil (Valdés et al., 2006; Caballer Gutiérrez et al., 2015) and Panama (present study).

\section{Notes}

This species was found in Sargassum algae with sertularid hydroids in this study.

Genus Phidiana Gray, 1850

Phidiana lynceus Bergh, 1867

(Fig. 7e)

\section{Synonyms}

Phidiana selencae Bergh, 1879; Phidiana brevicauda Engel, 1925.

\section{Description}

Body elongate and narrow. Rhinophores annulate, oral tentacles long. Cerata elongate densely covering the dorsum, except for the dorsal mid-line. Background color translucent gray with a dorsal white line that splits on the head and continues into the oral tentacles. The line can be narrow, broad or absent. Cerata with white apices. Orange pigment on the oral tentacles and rhinophores. Up to $45 \mathrm{~mm}$ long.

\section{Distribution}

Florida, Mexico, Costa Rica, Panama, Colombia, Venezuela, Curaçao, Aruba, Bonaire, Jamaica, Bahamas, Virgin Islands, 
Guadeloupe, Martinique, St. Maarten/St. Martin, St. Lucia, Barbados, St. Vincent and the Grenadines, Brazil. Ghana, Canary Islands (Valdés et al., 2006; García-García et al., 2008).

\section{Notes}

Found under rocks in this study. Known to feed on hydroids (McDonald \& Nybakken, 1997). Shows intraspecific variation in rhinophores and head morphology (Valdés et al., 2006).

Genus Palisa Edmunds, 1964

Palisa papillata Edmunds, 1964

(Fig. 7f)

\section{Description}

Body elongate. Rhinophores tuberculate; oral tentacles long. Cerata arranged in clusters forming a single row along each side of the dorsum. Background color translucent gray with numerous opaque white spots on both the dorsum and cerata. Cerata with a pale blue digestive gland and characteristic black or dark brown spots at the base. Up to $15 \mathrm{~mm}$ long.

\section{Distribution}

Florida, Jamaica (Valdés et al., 2006) and Panama (present study).

\section{Notes}

Found among algae in this study, probably feeding on epiphytic hydroids.

Genus Dondice Er. Marcus, 1958

Dondice occidentalis Engel, 1925

(Fig. 7g)

\section{Description}

Body elongate, tapering toward the posterior end. Rhinophores annulate, long; oral tentacles longer than the rhinophores. Cerata arranged in clusters along two rows on the dorsum. Background color translucent gray with a yellow or orange median line of variable width, running from the head to the anterior end, between the rhinophores. A white or blue broken line down the dorsal mid-line from behind the rhinophores to the posterior end of the body is sometimes present. Opaque white spots sometimes present on the dorsum. Oral tentacles translucent or light blue at the base, becoming white towards the tips. Cerata translucent gray, often with large blue or white bands covering the upper two-thirds of each ceras. Up to $50 \mathrm{~mm}$ long.

\section{Distribution}

Florida, Mexico, Belize, Costa Rica, Colombia, Venezuela, Curaçao, Bonaire, Venezuela, Bermudas, Bahamas, Cayman Islands, Jamaica, Turks and Caicos, Grenada, St. Maarten/St. Martin, Martinique, Trinidad, Brazil (Valdés et al., 2006; Caballer Gutiérrez et al., 2015) and Panama (present study).

\section{Notes}

Found on hydroids in this study. This species feeds on hydroids of the genus Eudendrium and Amathia Lamouroux, 1812 (see McDonald \& Nybakken, 1999). It easily sheds the cerata when disturbed. According to Gonzalez et al. (2013), Dondice occidentalis and Dondice parguerensis probably represent an example of incipient sympatric speciation. Molecular analyses support partially the differentiation of these species, but are inconclusive. Further research is needed in order to resolve this species complex.

Dondice parguerensis Brandon \& Cutress, 1985

(Fig. 7h)

\section{Description}

Body elongate, tapering toward the end. Rhinophores annulate, oral tentacles long. Cerata abundant, arranged in clusters along two rows on the dorsum. Background color translucent brown with a white median line from the head that extends posteriorly. Oral tentacles and rhinophores both translucent brown at the base and white on the distal half. Cerata translucent brown with white tips. Up to $48 \mathrm{~mm}$ long.

\section{Distribution}

Puerto Rico, Panama, Venezuela, Guadeloupe (Collin et al., 2005; Valdés et al., 2006; Mariño et al., 2011; Ortea et al., 2013).

\section{Notes}

This species is found exclusively on the tentacles of the upside-down jellyfish Cassiopea Péron \& Lesueur, 1810 in shallow mangrove areas. The divergence of this species from the close relative Dondice occidentalis was recently investigated by Gonzalez et al., 2013 (see above). Previously reported from Panama as $D$. occidentalis (Collin et al., 2005).

Family Aeolidiidae Gray, 1827

Genus Berghia Trinchese, 1877

Berghia rissodominguezi Muniain \& Ortea, 1999

(Fig. 8a) 


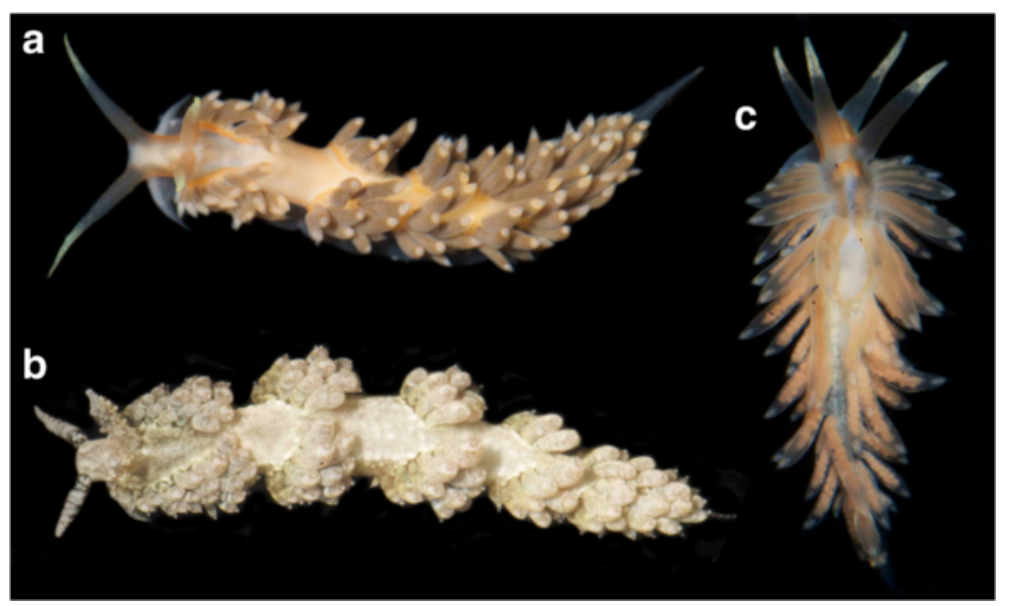

Fig. 8 Nudipleura: Aeolidiidae. a Berghia rissodominguezi Muniain \& Ortea, 1999; b Berghia creutzbergi Er. Marcus \& Ev. Marcus, 1970; c Anteaeolidiella lurana (Ev. Marcus \& Er. Marcus, 1967)

\section{Description}

Body narrow and elongate. Oral tentacles longer than the rhinophores. Cerata moderately elongate, cylindrical, with round apices and constant diameter throughout most of their length. Rhinophores densely papillate on the posterior side. Background color translucent white with oblique orange lines on the borders of the insertion of the cerata. Cerata translucent with reddish brown diverticula and white to yellow apices. Rhinophores bright orange with yellow or cream pigmentation on the apical portion. Up to $52 \mathrm{~mm}$ long.

\section{Distribution}

Florida, Venezuela, Curaçao, Jamaica, St. Lucia, Guadeloupe, Brazil, Argentina (Valdés et al., 2006; Carmona et al., 2014b; Ortea et al., 2013; Caballer Gutiérrez et al., 2015) and Panama (present study).

\section{Notes}

Found under rocks in intertidal areas in this study. Feeds on anemones. It can autotomize the cerata when being handled. Carmona et al. (2014b) clarified the misidentifications that had been published for the western Atlantic.

\section{Berghia creutzbergi Er. Marcus \& Ev. Marcus, 1970}

(Fig. 8b)

\section{Synonyms}

Milleria ritmica Ortea, Caballer \& Espinosa, 2003.

\section{Description}

Body elongate. Rhinophores tuberculate. Cerata arranged in two rows of clusters along the dorsum. Background color translucent gray or brown with numerous opaque white spots covering the majority of the dorsum and cerata. Cerata with longitudinal opaque white lines and white, narrow tips. Up to $30 \mathrm{~mm}$ long.

\section{Distribution}

Tropical western Atlantic, Florida, Costa Rica, Venezuela, Cuba, Barbados, Bahamas, Cayman Islands, Curaçao, Brazil (Valdés et al., 2006; Carmona et al., 2014b) and Panama (present study).

\section{Notes}

The single specimen in this study was found under a rock in a seagrass bed. The cerata of this species rock from side to side distinctively while the animal is in motion (Valdés et al., 2006). The genus Berghia was recently confirmed as the correct placement for this species (Carmona et al., 2014b).

Genus Anteaeolidiella M.C. Miller, 2001

Anteaeolidiella lurana (Ev. Marcus \& Er. Marcus, 1967)

(Fig. 8c)

\section{Description}

Body elongate. Rhinophores smooth, about the same length as the oral tentacles. Cerata covering most of the dorsum except for the dorsal mid-line. Background color translucent gray with orange pigmentation on the head, behind the rhinophores, and along the edges of the dorsum. Rhinophores and oral tentacles with cream or yellow tips. Cerata translucent with orange digestive diverticula and white cnidosacs. Up to $10 \mathrm{~mm}$ long.

\section{Distribution}

Amphiatlantic. Western Atlantic: Caribbean Sea, Brazil, Bermuda (Carmona et al. 2014a; Caballer Gutiérrez et al., 2015) and Panama (present study). 


\section{Notes}

Carmona et al. (2013) recently confirmed the validity of the genus Anteaeolidiella. Additional information on this species can be found in Carmona et al. (2014a).

Clade Euopisthobranchia Jörger, Stöger, Kano, Fukuda, Knebelsberger \& Schrödl, 2010

Order Cephalaspidea P. Fischer, 1883

Family Haminoeidae Pilsbry, 1895

Genus Haminoea Turton \& Kingston, 1830

Haminoea elegans (Gray, 1825)

(Fig. 9a)

\section{Synonyms}

Bulla guildinguii Swainson, 1840; Bulla diaphana Gould, 1852; Haminoea taylorae Petuch, 1987.

\section{Description}

Shell external, thin, translucent. Body wide and elongate, with large parapodia covering the anterior part of the shell. Shell with numerous and conspicuous spiral grooves crossed by growth lines. Cephalic shield deeply notched with reduced tentacles. Background color translucent yellowish gray with numerous black and opaque white. Up to $35 \mathrm{~mm}$ long.

\section{Distribution}

Florida to Brazil, Greater and Lesser Antilles, Bermuda and Bahamas (Valdés et al., 2006; Camacho-García et al., 2014).

\section{Notes}

Found on dense bacterial mats in shallow water, about $1 \mathrm{~m}$ depth.

\section{Haminoea succinea (Conrad, 1846)}

(Fig. 9b)

\section{Synonyms}

Haminoea solidor Vanatta, 1901.

\section{Description}

Shell external, rounded, translucent white. Body elongate, with a short and broad cephalic shield having two lateral, very short and wide extensions. Parapodia very short, not covering any portion of the shell. Posterior end of the foot broad and rounded. Background color

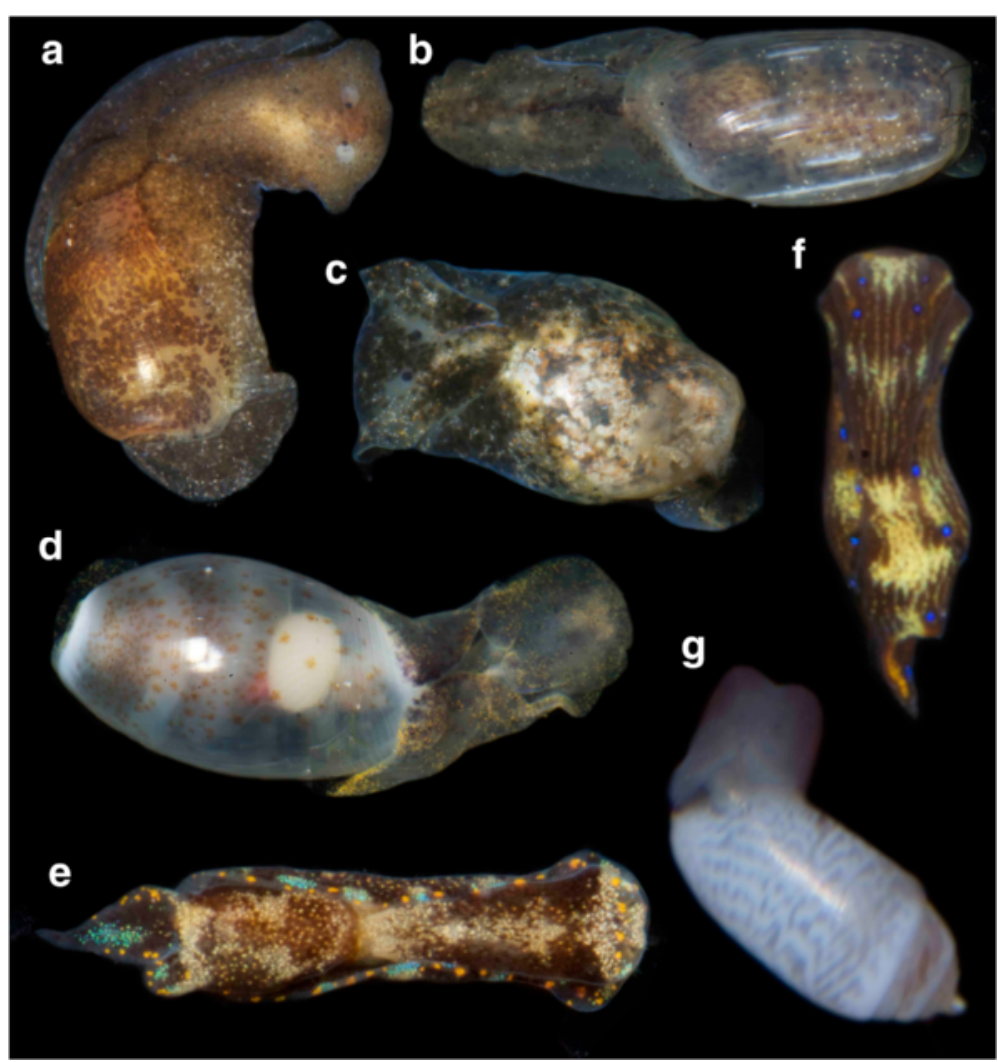

Fig. 9 Euopisthobranchia: Haminoeidae, Aglajidae and Acteocinidae. a Haminoea elegans (Gray, 1825); b Haminoea succinea (Conrad, 1846); c Haminoea antillarum (d'Orbigny, 1841); d Atys caribaeus (d'Orbigny, 1841); e Chelidonura berolina Er. Marcus \& Ev. Marcus, 1970; f Navanax gemmatus (Mörch, 1863); g Acteocina candei (d'Orbigny, 1842) 
translucent gray with numerous black spots and some opaque white dots. Up to $20 \mathrm{~mm}$ long.

\section{Distribution}

Florida. Louisiana, Texas, Mexico, Colombia, Venezuela, Bermuda, Puerto Rico, St. Maarten/St. Martin, St. Barthelemy (Valdés et al., 2006) and Panama (present study).

\section{Notes}

Found on soft bottoms in protected areas near mangrove roots in this study.

\section{Haminoea antillarum (d'Orbigny, 1841)}

(Fig. 9c)

\section{Synonyms}

Bulla cerina Menke, 1853; Haminea guadaloupensis G.B. Sowerby II, 1868.

\section{Description}

Shell external, rounded, lacking any marking other than light growth lines. Shell translucent, showing through the viscera with orange and dark brown spotting. Cephalic shield with two extensions visible. Head with two conspicuous eye spots on the dorsal side. Foot broad on the posterior end. Small parapodial flaps cover the anterior portion of the shell. Up to $40 \mathrm{~mm}$ long.

\section{Distribution}

From Florida to Brazil, including Cuba, Cayman Islands, Jamaica, Puerto Rico, Virgin Islands, Guadeloupe, Bermuda (Valdés et al., 2006; García-García et al., 2008; Caballer Gutiérrez et al., 2015).

\section{Notes}

Typically found on red algae in highly turbulent areas. As with other Haminoeidae, this species is herbivorous (Capper \& Paul, 2008). It is a common species in the intertidal zone.

Genus Atys Leach, 1816

Atys caribaeus (d'Orbigny, 1841)

(Fig. 9d)

\section{Synonymy}

Bulla speciosa A. Adams, 1850.

\section{Description}

Shell external, elongate, translucent, with conspicuous spiral grooves near the anterior and posterior ends. Body very elongate, with a deeply notched cephalic shield (posteriorly). Parapodia short, covering a small portion of the anterior end of the shell. Background color translucent white with irregular opaque white spots and some black dots, sometimes with a dense covering of brown dots. Shell sometimes with brown patches. Up to $20 \mathrm{~mm}$ long.

\section{Distribution}

North Carolina, Florida to Brazil, Greater and Lesser Antilles (Valdés et al., 2006).

\section{Notes}

Found on soft bottoms near mangrove roots in this study.

Family Aglajidae Pilsbry, 1895

Genus Chelidonura A. Adams, 1850

Chelidonura berolina Er. Marcus \& Ev. Marcus, 1970

(Fig. 9e)

\section{Description}

Shell reduced, internal. Body elongated with a cephalic shield slightly longer than the visceral hump. Posterior end of the body with two lobes, the left one being much longer. Background color black with a submarginal yellow band on the parapodial edge, posterior end of the cephalic shield and anterior and posterior ends of the body. Anterior edge of the body translucent. Dorsum covered by white and yellow patches in some specimens, not present in others. Up to $12 \mathrm{~mm}$ long.

\section{Distribution}

From Mexico to Colombia, Cayman Islands, Cuba, Jamaica, Martinique, Puerto Rico, Bermuda, Bahamas (Valdés et al., 2006; Ornelas-Gatdula et al., 2011; Malaquias, 2014).

\section{Notes}

Common on shallow sandy areas as it buries itself in the sand, can be found crawling among seagrass at daytime (Valdés et al., 2006; Malaquias, 2014). A taxonomic revision of Chelidonura in the Caribbean was recently published (Ornelas-Gatdula et al., 2011).

Genus Navanax Pilsbry, 1895

Navanax gemmatus (Mörch, 1863)

(Fig. 9f)

\section{Synonyms}

Aglaja hummelincki Er. Marcus \& Ev. Marcus, 1970.

\section{Description}

Shell reduced, internal. Body elongated with well-formed cephalic shield and parapodia. Posterior end of the body with two lobes, the left one with a thin elongate projection. Background color from opaque yellow to dark brown. Dorsum with white and brown longitudinal lines and 
some whitish areas. Edge of the parapodia with a row of bright blue spots. Up to $50 \mathrm{~mm}$ long.

\section{Distribution}

From Florida to Brazil, Lesser Antilles, Cuba, Jamaica, Bahamas, Bermuda (Valdés et al., 2006; Ornelas-Gatdula et al., 2012; Camacho-García et al., 2014; Caballer Gutiérrez et al., 2015).

\section{Notes}

Feeds on other sea slugs and inhabits rocky areas (Valdés et al., 2006). Ornelas-Gatdula et al. (2012) studied the Navanax aenigmaticus (Bergh, 1893) species complex using morphological and molecular data and proposed that the valid species name for the Western Atlantic species was Navanax gemmatus.

Family Acteocinidae Dall, 1913

Genus Acteocina Gray, 1847

Acteocina candei (d'Orbigny, 1842)

(Fig. 9g)

\section{Description}

Shell external, solid, oval to elongate. Spire long, conical, with 2-3 channeled whorls. Umbilicus absent. Columellar margin thickened, slightly oblique, with a small, simple fold. Head with two large posterior lobes, parapodia absent. Background color translucent white. Shell translucent white with the viscera visible as an irregular pattern of white pigment on a slightly reddish background. Up to $5.3 \mathrm{~mm}$ long.

\section{Distribution}

North Carolina, Texas, Florida to Brazil, Argentina, Bermuda, Bahamas, Cuba, Jamaica, Puerto Rico, Virgin Islands, Guadeloupe, Martinique, Guyana (Valdés et al., 2006; Caballer Gutiérrez et al., 2015) and Panama (present study).

\section{Notes}

Found on soft bottoms near mangrove roots in this study.

Order Anaspidea Fischer, 1883

Suborder Aplysioidea Lamarck, 1809

Family Aplysiidae Lamarck, 1809

Genus Aplysia Linnaeus, 1767

Aplysia dactylomela Rang, 1828

(Fig. 10a)

\section{Synonyms}

Aplysia protea Rang, 1828; Aplysia schrammi Deshayes, 1857; Aplysia aequorea Heilprin, 1888; Aplysia megaptera Verrill, 1900.

\section{Description}

Shell reduced, internal. Body elongated with two tough and leathery parapodia that cover the mantle cavity. Rhinophores rolled, oral tentacles reduced. Background color usually greenish brown with large dark or black rings, which are characteristic of this species. Dark or black reticulate lines also present. Up to $200 \mathrm{~mm}$ long.

\section{Distribution}

Amphiatlantic. Western Atlantic: from Florida to Brazil, Greater and Lesser Antilles (Valdés et al., 2006; Alexander \& Valdés, 2013; Caballer Gutiérrez et al., 2015).

\section{Notes}

This species produces purple ink when disturbed and animals mate in chains (Valdés et al., 2006). Atlantic populations were recently classified as Aplysia dactylomela and separated from the Indo-Pacific Aplysia argus Rüppell \& Leuckart, 1830 (Alexander \& Valdés, 2013). Aplysia dactylomela has been introduced into the Mediterranean sea (Valdés et al., 2013). Found on algae and an algae covered reef in this study.

Genus Stylocheilus Gould, 1852

Stylocheilus striatus (Quoy \& Gaimard, 1832)

(Fig. 10b)

\section{Synonyms}

Notarchus polyomma Mörch, 1863; Stylocheilus lineolatus Gould, 1852.

\section{Description}

External shell present in juveniles but lost in adults. Body elongated with numerous branched papillae. Background color translucent with shades of cream, brown, and grey. Body with longitudinal or interrupted dark lines and scattered spots. Adults often have bright pink or blue ocelli that are not found in juveniles. Up to $45 \mathrm{~mm}$ long.

\section{Distribution}

Circumtropical. Western Atlantic: from Florida to Brazil, Greater Antilles and Lesser Antilles, Bermuda, Bahamas (Valdés et al. 2006; Camacho-García et al., 2014; Caballer Gutiérrez et al., 2015).

\section{Notes}

Organism feeds on algae and is common in shallow waters. This species has been often assigned to Stylocheilus longicaudus (Quoy \& Gaimard, 1825), which is a pelagic species associated with floating algae (Valdés et al., 2006).

Genus Dolabrifera Gray, 1847

Dolabrifera dolabrifera (Rang, 1828)

(Fig. 10c) 


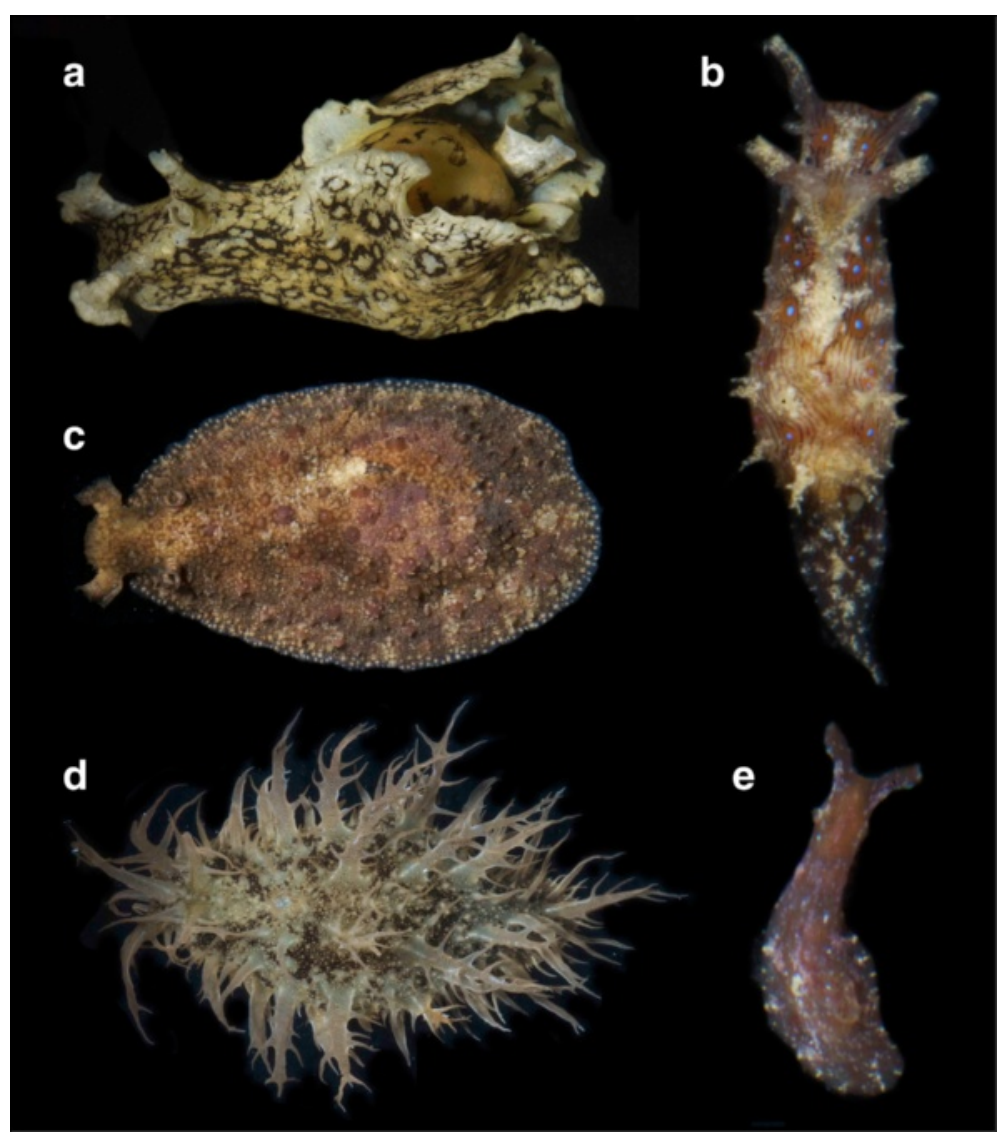

Fig. 10 Euopisthobranchia: Aplysiidae. a Aplysia dactylomela Rang, 1828; b Stylocheilus striatus (Quoy \& Gaimard, 1832); c Dolabrifera dolabrifera (Rang, 1828); d Bursatella leachii Blainville, 1817; e Phyllaplysia engeli Er. Marcus, 1955

\section{Synonyms}

Aplysia ascifera Rang, 1828; Aplysia oahouensis Souleyet, 1852; Dolabrifera cuvieri H. \& A. Adams, 1854; Dolabrifera maillardi Deshayes, 1863; Dolabrifera nicaraguana Pilsbry, 1896; Dolabrifera olivacea Pease, 1860; Dolabrifera sowerbyi G. B. Sowerby II, 1868; Dolabrifera swiftii Pilsbry, 1896; Dolabrifera virens Verrill, 1901.

\section{Description}

Body flattened and tapered anteriorly, with the posterior end usually broader and more rounded. Parapodia fused except for a very small region in the posterior mid-line. Dorsum covered with low tubercles. Background color varies from mottled green to brown (light or dark) to even pink. Up to $90 \mathrm{~mm}$ long.

\section{Distribution}

Circumtropical. Western Atlantic: North and south American mainland, from Florida to Brazil, Greater and Lesser Antilles, Bermuda, Bahamas (Valdés et al., 2006; Camacho-García et al., 2014).

\section{Notes}

Feeds on patches of algae on rocks. This species can be very abundant in intertidal rocky areas and crawls with a leach-like movement (Valdés et al., 2006).

Genus Bursatella Blainville, 1817

Bursatella leachii Blainville, 1817

(Fig. 10d)

\section{Synonyms}

Notarchus laciniatus Rüppell \& Leuckart, 1830; Aplysia bursatella Rang, 1834; Aclesia glauca Cheeseman, 1878; Notarchus intrapictus Cockerell, 1893; Aclesia africana Engel, 1926; Aclesia rosea Engel, 1926; Bursatella lacinulata Gould, 1852; Bursatella leachii lacinulata Gould, 1852.

\section{Description}

Body rounded, wider towards the posterior end. Head with two rhinophores on the dorsal side and two oral tentacles one on either side of the mouth. Dorsum covered with many papillae along, which gives the animal a fuzzy appearance. Body color dark green to dark brown 
with some lighter colored spots. The gill is on the dorsal side covered by two parapodial flaps. Up to $120 \mathrm{~mm}$ long, but typically $75-100 \mathrm{~mm}$.

\section{Distribution}

Circumtropical. Western Atlantic: from North Carolina to Brazil, Virgin Islands, Jamaica, Aruba, Curaçao, Bermuda, Trinidad (Valdés et al., 2006; Caballer Gutiérrez et al., 2015).

\section{Notes}

Found in tide pools, lagoons and estuaries. This species lives in sea grass beds, feeds on algae and lays long, thin, ribbon-like egg masses. It is currently considered to be circumtropical species, but made up of several subspecies. The subspecies found in the Caribbean is Bursatella leachii pleii Rang, 1828 (Valdés et al., 2006).

Genus Phyllaplysia P. Fischer, 1872

Phyllaplysia engeli Er. Marcus, 1955

(Fig. 10e)

\section{Description}

Body flattened and oval, some specimens with low papillae. Parapodia fused. Background color translucent with varying patches and spots of pink, brown, white and some green. Some specimens have white longitudinal lines. Up to $15 \mathrm{~mm}$ long.

\section{Distribution}

Florida to Brazil, Curaçao, Bahamas, Puerto Rico, Jamaica, St. Maarten/St. Martin, Barbados (Valdés et al., 2006; Caballer Gutiérrez et al., 2015).

\section{Notes}

Found on sea grasses of the genera Thalassia Banks ex König, 1805 and Halodule Endlicher, 1841 on which they are extremely cryptic (Valdés et al., 2006).

Clade Panpulmonata Jörger, Stöger, Kano, Fukuda, Knebelsberger \& Schrödl, 2010

Order Sacoglossa Ihering, 1876

Family Volvatellidae Pilsbry, 1895

Genus Ascobulla Ev. Marcus, 1972

Ascobulla ulla (Er. Marcus \& Ev. Marcus, 1970)

(Fig. 11a)

\section{Description}

External shell slightly calcified with a cylindrical shape and flat apex. Eyes present and positioned in the upper region of the head, covered by the cephalic shield during locomotion and digging, making it difficult to observe in living animals. Cephalic shield has two lobes divided by a deep groove. Translucent shell, mantle and visceral mass define the body color, varying between brown and orange. Head shield has white coloration and opaque white dots on its surface. Up to $6 \mathrm{~mm}$ long.

\section{Distribution}

Florida, Mexico, Belize, Costa Rica, Venezuela, Bermuda, Bahamas, Turks and Caicos, Cayman Islands, Virgin Islands, Brazil (Valdés et al., 2006; Camacho-García et al., 2014) and Panama (present study).

\section{Notes}

Found on different species of Caulerpa Lamouroux, 1809, most commonly on rhizoids of Caulerpa racemosa Agardh, 1873 or crawling on sand next to algae. May exude a milky substance when disturbed. Fragile shell easily cracked or broken when handled.

Family Oxynoidae Stoliczka, 1868 (1847)

Genus Oxynoe Rafinesque, 1814

Oxynoe antillarum Mörch, 1863

(Fig. 11b)

\section{Description}

Body elongate with long posterior end of foot resembling a tail. Shell globose and translucent, fragile with a wide opening and partially or fully covered by parapodia in adults. Smaller juvenile parapodia expose much of the shell. Rolled rhinophores prominent. Groove runs horizontally from base of rhinophores through each lateral region of the head. Body color light green with white papillae on parapodial margins and running down midline of tail. White and blue patches on rhinophores, sides of head, and parapodial margins. Juvenile body more elongated and smooth, ground color solid yellow to green with white and blue patches along, or at base of, rhinophores; some blue spots on mantle may be visible through shell. Up to $20 \mathrm{~mm}$ long.

\section{Distribution}

Florida, Mexico, Belize, Honduras, Costa Rica, Panama, Venezuela, Bahamas, Curaçao, Bermuda, Cayman Islands, Jamaica, Dominican Republic, Puerto Rico, Virgin Islands, Martinique, St. Lucia, Barbados, St. Vincent and the Grenadines, Grenada, Trinidad and Tobago, Brazil (Valdés et al., 2006; Camacho-García et al., 2014).

\section{Notes}

Very common throughout the tropical western Atlantic coast on many species of Caulerpa, but primarily on Caulerpa racemosa. Specimens sometimes found under rocks or crawling next to algae. Exudes white secretion and may autotomize tail when disturbed. High intraspecific variation and a lack of diagnostic differences in 


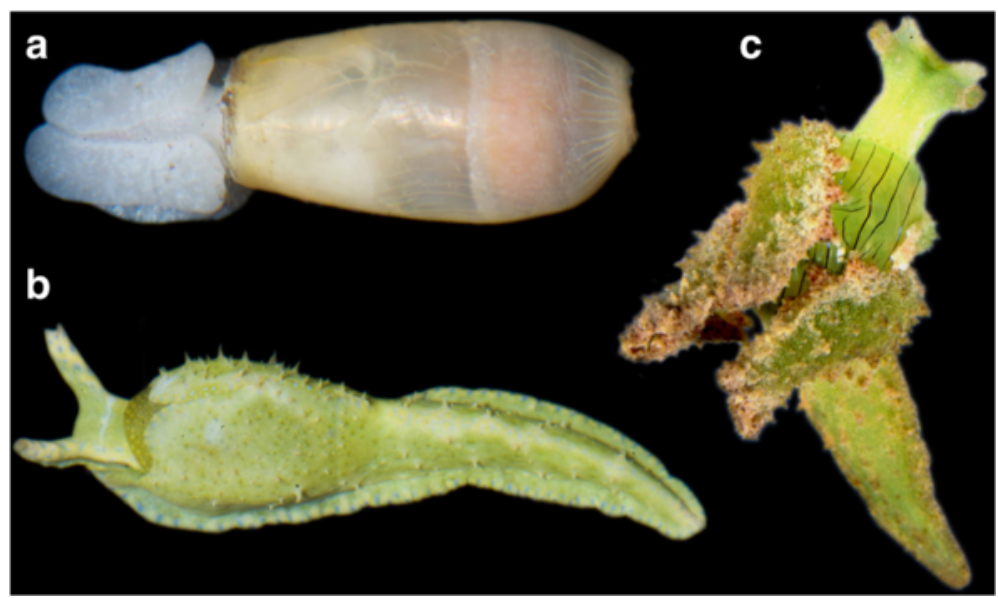

Fig. 11 Panpulmonata: Volvatellidae and Oxynoidae. a Ascobulla ulla (Er. Marcus \& Ev. Marcus, 1970); b Oxynoe antillarum Mörch, 1863; c Lobiger souverbii Fischer, 1857

external morphology make it difficult to distinguish from Oxynoe azuropunctata Jensen, 1980.

Genus Lobiger Krohn, 1847

Lobiger souverbiei P. Fischer, 1857

(Fig. 11c)

\section{Synonyms}

Lobiger pilsbryi Schwengel 1941.

\section{Description}

Shell extremely fragile with apex directed posteriorly to left side. Some small papillae scattered on rhinophores and lateral sides of the head. Each parapodium expands narrowly in two leaf-like projections upwards from shell, with white papillae on parapodial margins. Rolled rhinophores shorter than head. Foot extends posteriorly to form thick tail and anteriorly to form two lobes. Body coloration light green with yellowish-brown papillae on tail and parapodia. Light green mantle with black longitudinal lines and a few scattered blue dots visible through translucent shell. Up to $30 \mathrm{~mm}$ long.

\section{Distribution}

Florida, Mexico, Honduras, Costa Rica, Venezuela, Curaçao, Cayman Islands, Jamaica, Puerto Rico, Guadeloupe, Barbados, St. Vincent and the Grenadines, Grenada, Brazil (Valdés et al., 2006; Camacho-García et al., 2014) and Panama (present study).

\section{Notes}

Feeds on Caulerpa spp., most commonly found on Caulerpa racemosa in high-flow areas. May exude milky secretion and sometimes autotomize parapodial extensions when disturbed.
Family Limapontiidae Gray, 1847

Genus Ercolania Trinchese, 1872

Ercolania coerulea Trinchese, 1892

(Fig. 12a)

\section{Synonyms}

Stiliger cricetus Er. Marcus \& Ev. Marcus 1970.

\section{Description}

Cerata short and fusiform arranged in rows on both sides of body. Digestive diverticula irregular inside each ceras. Rhinophores simple, smooth, longer than head. Eyes in dorsolateral position. Pericardial hump short, not covered by cerata. Foot forms thick short tail and large rounded anterior expansion. Opaque translucent body with posterior region colored by yellow digestive gland. Small white dots scattered across entire body, highly concentrated on cerata and rhinophore tips. Some individuals have blue spots clustered at tips of cerata and rhinophores and on top of head. Two longitudinal light green branches of digestive diverticula run anteriorly, branching in cephalic region and inside rhinophores. Body length typically $8-10 \mathrm{~mm}$, up to $16 \mathrm{~mm}$.

\section{Distribution}

Florida, Venezuela, Curaçao, Jamaica, Virgin Islands, St. Kitts, St. Lucia, Brazil (Valdés et al., 2006) and Panama (present study).

\section{Notes}

Found in clumps of the green bubble algae Dictyosphaeria cavernosa Børgesen, 1932 and Valonia Agardh, 1823. Originally described from Mediterranean Sea, only species of the genus Ercolania recorded from the Atlantic and Indo-Pacific (Grzymbowski et al., 2007). Recent phylogenetic analysis confirmed placement of $E$. coerulea 


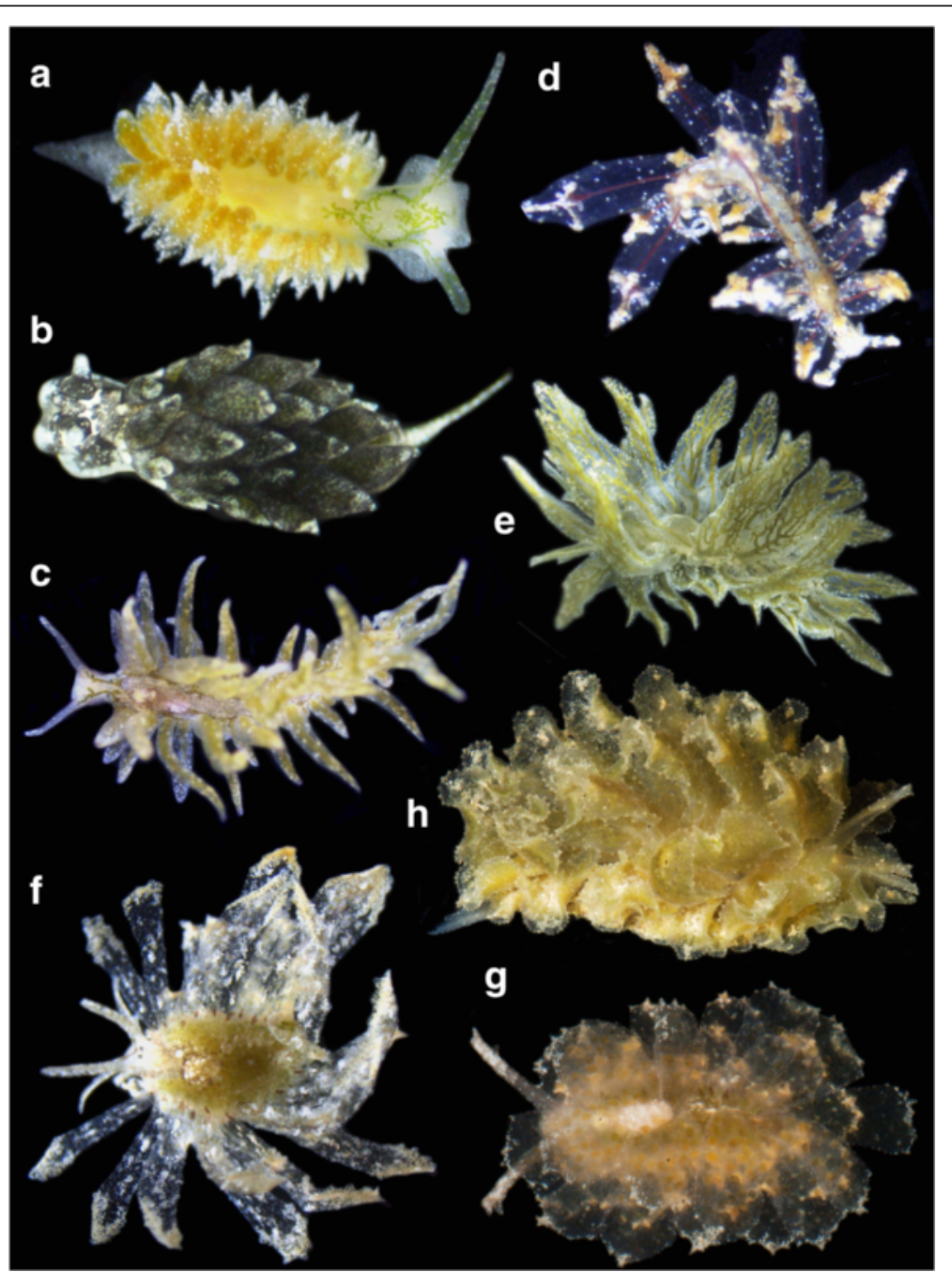

Fig. 12 Panpulmonata: Caliphyllidae, Costasiellidae, Hermaeidae and "Limapontiidae". a Ercolania coerulea Trinchese, 1892; b Costasiella nonatoi Ev. Marcus \& Er. Marcus, 1960; c Placida kingstoni Thompson, 1977; d Hermaea cruciata Gould, 1870; e Caliphylla mediterranea Costa, 1867; f Cyerce antillensis Engel, 1927; g Cyerce cf. antillensis Engel, 1927; h Polybranchia viridis (Deshayes, 1857)

within a larger clade that includes most other species in the genus (Krug et al., 2015).

Family Costasiellidae K. B. Clarke, 1984

Genus Costasiella Pruvot-Fol, 1951

Costasiella nonatoi Ev. Marcus \& Er. Marcus, 1960

(Fig. 12b)

\section{Description}

Grooved rhinophores shorter than head. Foot elongated posteriorly in sharp tail longer than half the body length and anteriorly wide and bilobate. Eyes mid-dorsally positioned behind rhinophores. Largest fusiform cerata arranged in dorsal region, while small ones in one row next to foot corner. Overall external color almost entirely black, except for tail, periocular area, border of foot, and tips of rhinophores and cerata, which are transparent or opaque white. Bright whitish or yellowish dots dispersed through foot, rhinophores, cerata, and tail. Up to $4 \mathrm{~mm}$ long.

\section{Distribution}

North Carolina, Florida, Costa Rica, Venezuela, Cayman Islands, Puerto Rico, Bahamas, Bermuda, Brazil (Valdés et al., 2006; Camacho-García et al., 2014; Caballer Gutiérrez et al., 2015) and Panama (present study).

\section{Notes}

Feeds and reproduces on Avrainvillea Descaisne, 1842 spp. and crawls among its filaments. Phylogenetic analysis places $C$. nonatoi outside monophyletic group formed by other species of the genus (Krug et al., 2015). Characteristics such as grooved rhinophores, eyes positioned behind rhinophores, and absence of photosynthetic ability also 
distinguish it from other species of Costasiella (Christa et al., 2014; Jensen et al., 2014).

Genus Placida Gray, 1847

Placida kingstoni Thompson, 1977

(Fig. 12c)

\section{Description}

Opaque translucent body scattered with small white dots, brown dorsal region. Two longitudinal yellow-green digestive system branches run along dorsal region, branching anteriorly next to rhinophores. Elongated fusiform cerata, each containing one unbranched ramification of the digestive diverticula extending almost to tip. Rhinophores enrolled at base, smooth, longer than head. Eyes in a dorsolateral position closer to pericardial hump than to rhinophores. Prominent pericardial hump visible on dorsal region, longer than head. Anal papillae positioned midanteriorly on pericardial hump. Foot forms a short tail and small square anterior expansion. Up to $15 \mathrm{~mm}$ long.

\section{Distribution}

Florida, Costa Rica, Jamaica, Martinique, Bermuda (Valdés et al., 2006) and Panama (present study).

\section{Notes}

Found on green algae in the genus Bryopsis Lamouroux, 1809.

Family Hermaeidae Adams \& Adams, 1854

Genus Hermaea Lovén, 1844

Hermaea cruciata Gould, 1870

(Fig. 12d)

\section{Synonyms}

Hermaea coirala Er. Marcus 1955.

\section{Description}

Rhinophores bifurcated and slightly longer than the head. Foot forms sharp tail posteriorly and projects anteriorly into small foot corner extensions. Cerata fusiform with a conical tip, variable in size. Largest cerata reaching more than half the body length. A duct of the digestive system run inside each ceras and branches highly only in the apex under the yellow gland. Translucent body with scattered small white dots. Dark red tubules of digestive diverticula, yellow glands at tips of cerata, whitish gonads, and other internal organs visible through translucent body wall. Up to $5 \mathrm{~mm}$ long.

\section{Distribution}

Massachusetts, New York, Florida, Costa Rica, Trinidad and Tobago, Brazil (Valdés et al., 2006) and Panama (present study).

\section{Notes}

Species of Hermaea often feed on filamentous red algae (Caballer \& Ortea, 2013), as opposed to the green algae that serve as host for most sacoglossans.

Family Caliphyllidae Tiberi, 1881

Genus Caliphylla A. Costa, 1867

Caliphylla mediterranea A. Costa, 1867

(Fig. 12e)

\section{Description}

Each side of the body has four rows of leaf-shaped cerata. Dorsal midline lacking cerata, starting at the pericardium. Digestive diverticula branch within cerata, bifurcating at margin of each ceras. Oral veil is present. Anus at apex of papilla on right side, at eye level anterior to pericardium. Bifid rhinophores long and grooved. Eyes positioned on median side behind rhinophores. Male genital pore at base of rhinophores, female aperture anus and male pore. Digestive diverticula, varying from dark green to brown, visible through translucent elongated body. Numerous black and white dots scattered throughout body. Up to $35 \mathrm{~mm}$ long.

\section{Distribution}

Amphiatlantic; Western Atlantic: Florida, Curaçao, Virgin Islands, Trinidad and Tobago, Brazil (Valdés et al., 2006) and Panama (present study).

\section{Notes}

Associated with filamentous green algae Bryopsis plumosa Agardh, 1823 growing in sheltered areas of rocks, reef corals or mangrove roots. Readily shed cerata and extrude adhesive substance when disturbed. Monotypic genus with type specimen from Mediterranean Sea, but other morphotypes from West Atlantic coast may reveal one or more additional species (Valdés et al., 2006), and at least one cryptic species exists in the Pacific (Krug et al., 2015).

Genus Cyerce Bergh, 1870

Cyerce antillensis Engel, 1927

(Fig. 12f)

\section{Synonyms}

Cyerce habanensis Ortea \& Templado 1989.

\section{Description}

Body broad and oval-shaped. Eye spots behind base of rhinophores. Body translucent with light green to yellowwhite viscera showing through. Pericardium opaque white. Cerata wide and inflated, almost transparent with scattered white spots that concentrate at the tips and irregular edges. Up to $60 \mathrm{~mm}$ long. 


\section{Distribution}

Florida, Mexico, Belize, Honduras, Costa Rica, Curaçao, Bermuda, Cayman, Islands, Cuba, Bahamas, Jamaica, Puerto Rico, Virgin Islands, Barbados, Tobago (Valdés et al., 2006; Camacho-García et al., 2014) and Panama (present study).

\section{Notes}

Feeds on green algae in the genus Penicillus Lamarck, 1813; older reports of other hosts (Udotea Lamouroux, 1812, Halimeda Lamouroux, 1812) likely reflect unrecognized cryptic species that eat other host genera (Jensen \& Clark, 1983; Clark \& DeFreese, 1987). May autotomize cerata when disturbed.

\section{Cyerce cf. antillensis Engel, 1927}

(Fig. 12g)

\section{Description}

Body broad and oval-shaped. Eye spots behind base of rhinophores. Body translucent with light green to yellowwhite viscera showing through. Pericardium opaque white. Cerata wide and short, almost transparent with orange spots and white at the tips and irregular edges. Up to $30 \mathrm{~mm}$ long.

\section{Distribution}

Panama (present study).

\section{Notes}

Feeds on Halimeda green algae. Similar to Cyerce antillensis but is genetically distinct (unpublished data), has a white pericardium and broader cerata; it may constitute an undescribed species. Autotomizes the cerata when disturbed.

Genus Polybranchia Pease, 1860

Polybranchia viridis (Deshayes, 1857)

(Fig. 12h)

\section{Description}

Body oval-shaped. Rhinophores bifid for half of their length or more, cerata and rhinophores covered with small papillae. Body almost transparent with internal viscera giving the animal a light green to pale gold tint. Flattened cerata translucent with opaque white spots and characteristic fold in middle and numerous white glands on edges. Up to $80 \mathrm{~mm}$ long.

\section{Distribution}

Florida, Costa Rica, Curaçao, Bonaire, Jamaica, Virgin Islands, Guadeloupe, Barbados (Valdés et al., 2006) and Panama (present study).

\section{Notes}

Feeds on green algae in the genus Caulerpa. Found under rocks during the day and active at night.

Family Plakobranchidae Gray, 1840

Genus Elysia Risso, 1818

Elysia crispata Mörch, 1863

(Fig. 13a-b)

\section{Synonyms}

Elysia schrammi Ørsted \& Mörch, 1863; Tridachia whiteae Er. Marcus, 1957; Elysia clarki Pierce, Curtis, Massey, Bass, Karl \& Finney, 2006.

\section{Description}

Most conspicuous and one of the largest sacoglossans in the Caribbean. Parapodia highly undulated, resembling lettuce (hence the common name lettuce sea slug). Highly variable in body color, ranging from light to dark green with small or large white spots, to dark green or purple with white spotting (described as Elysia clarki), to entirely blue. Parapodial margins also highly variable in color - often white but can also be lined with yellow, red, and/or blue. Foot may be uniformly pale cream, or green with small to large white spots. Dorsal surface between parapodia generally pale green, often with pale cream to white spots. Up to $50 \mathrm{~mm}$ long.

\section{Distribution}

Florida, Dry Tortugas, Mexico, Belize, Honduras, Costa Rica, Colombia, Venezuela, Aruba, Curaçao, Bonaire, Venezuela, Bermuda, Cayman Islands, Bahamas, Jamaica, Haiti, Puerto Rico, Virgin Islands, St. Maarten/St. Martin, Antigua, St. Lucia, Martinique, Guadeloupe, Turks and Caicos, St. Vincent and the Grenadines, Barbados, Trinidad and Tobago (Valdés et al., 2006; CamachoGarcía et al., 2014) and Panama (Collin et al., 2005).

\section{Notes}

Very common throughout the Caribbean and easily spotted on rocks, coral rubble, or sediment, often crawling or sometimes stationary with parapodia opened giving the appearance of basking in the sun. Uncertainty surrounds feeding ecology, but thought to be highly polyphageous for a sacoglossan. The most recent work using field and lab methods confirmed feeding on one or more species in the genera Bryopsis, Penicillus, Halimeda, Acetabularia Lamouroux, 1812, and Derbesia Solier, 1846 (Pierce et al., 2003; Curtis et al., 2004, 2006; Middlebrooks et al., 2014). Originally described as Elysia (Tridachia) crispata, now formally recognized as a member of the genus Elysia.

Elysia ornata (Swainson, 1840)

(Fig. 13c) 


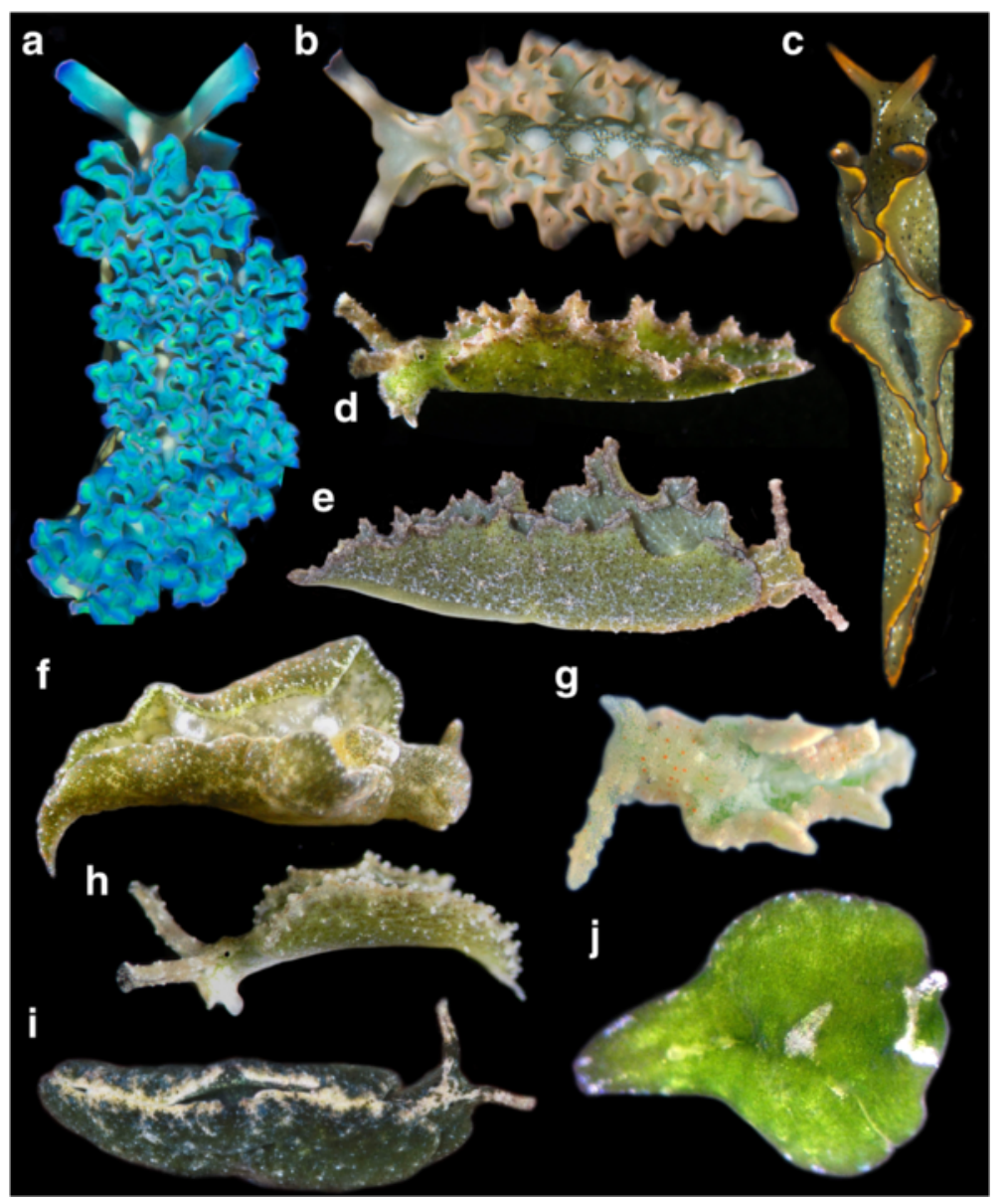

Fig. 13 Panpulmonata: Plakobranchidae. a-b Elysia crispata Mörch, 1863; c Elysia ornata (Swainson, 1840); d Elysia papillosa Verrill, 1901; e Elysia subornata Verrill, 1901; f Elysia canguzua Er. Marcus, 1955; g Elysia cornigera Nuttall, 1989; h Elysia zuleicae Ortea \& Espinosa, 2002; i Elysia velutinus Pruvot-Fol, 1947; j Elysia marcusi (Ev. Marcus, 1972)

\section{Synonyms}

Pterogasteron marginatum Pease 1871.

\section{Description}

Parapodia highly arched to form a prominent raised "chimney" halfway along the body, then unite at posterior end of body to a pointed tail. Rhinophores short and taper to a blunt point at rolled tips. Olive green with small black and white spots on dorsal surface and outer parapodia. Sharp black band runs along entire parapodial margin, with more diffuse orange submarginal band on inner and outer parapodia. Rhinophores match orange coloration of parapodia but may lack black edges. Up to $50 \mathrm{~mm}$ long.

\section{Distribution}

Florida, Belize, Honduras, Costa Rica, Colombia, Venezuela, Bahamas, Curaçao, Bermuda, Jamaica, Puerto Rico, Virgin Islands, Martinique, Turks \& Caicos, Barbados, St. Vincent and the Grenadines, Grenada, Trinidad and Tobago, Brazil (Valdés et al., 2006; Camacho-García et al., 2014) and Panama (present study).

\section{Notes}

Commonly found feeding inside clumps of Bryopsis plumosa and can be surprisingly cryptic despite relatively large size and bright coloration. This species was thought to have a cosmopolitan distribution, but recent molecular work suggests that the Caribbean population is genetically distinct from several undescribed species in the Indo-Pacific (Krug et al., 2013).

\section{Elysia papillosa Verrill, 1901}

(Fig. 13d)

\section{Synonymy}

Elysia annedupontae Ortea, Espinosa \& Caballer, 2005. 


\section{Description}

Outer parapodial surface covered with rows of white papillae. Parapodial margin tan to dark brown, bears many light tan to brown papillae, with scalloped edge forming several siphonal openings. One large pair of spermstorage vesicles visible on dorsal surface of large adults, usually near the $6^{\text {th }}$ dorsal vessel. Highly variable external body coloration, generally light green but can range from white/tan to olive green. Sides of head lighter green to white. One or two large white papillae between the eyes on most specimens. Inner parapodial surface and dorsum lightly to heavily speckled with brown or black spots, and with scattered white, rounded papillae. Pericardium round, with brown streaks and spots and low white papillae. Up to $30 \mathrm{~mm}$ long.

\section{Distribution}

Mexico, Panama, Cuba, Jamaica, Florida, Bahamas, U.S. Virgin Islands, Antigua, Curaçao (Krug et al., in press).

\section{Notes}

When disturbed, specimens readily swim by undulating their parapodia. Specializes on green algae in the genus Penicillus. One of the most abundant sacoglossans in the Caribbean - sometimes visible in the field and often found on collections of Penicillus spp. Often confused with E. zuleicae, which may be distinguished by its longer rhinophores and extended tail. Also readily confused with E. patina, which is externally very similar but can be distinguished by its host alga Halimeda opuntia Lamouroux, 1816 and its egg masses - E. papillosa produces relatively more numerous, larger eggs (planktotrophic development) with white extra-zygotic yolk, while E. patina has larger, fewer eggs (lecithotrophic development) with flat, orange ribbons of extra-zygotic yolk (Krug et al., in press).

\section{Elysia subornata Verrill, 1901}

(Fig. 13e)

\section{Description}

Coloration ranges from yellow to olive to dark green. Sides of parapodia dusted with white to varying degrees, with white pigment often arranged in star-shaped clusters around base of white papillae. Tiny black or brown dots scattered all over head and body. Some specimens have few papillae, others are densely covered in elongated white papillae. Rhinophores short relative to body length, with tan to lavender to dark brown coloration and white tips. Distinctive fine black line along the edge of parapodia, with tan to dark brown margin, sometimes with white speckling. Inner parapodia green with white speckling. Mostly symmetrical, simple vessels extending from center of dorsal surface. Up to $50 \mathrm{~mm}$ long.

\section{Distribution}

Florida, Mexico, Belize, Costa Rica, Bermuda, Bahamas, Aruba, Cayman Islands, Jamaica, Puerto Rico, Virgin Islands, Martinique, Grenada, Trinidad and Tobago, Brazil (Valdés et al., 2006; Camacho-García et al., 2014; Padula et al., 2012; Galvão Filho et al., 2015) and Panama (present study).

\section{Notes}

Egg masses have continuous string of bright orange extra-zygotic yolk, larvae metamorphose inside egg capsules (Krug et al., in press). Slugs are usually found in association with Caulerpa and are known to feed on at least eight different species in the genus. Adults do not swim when disturbed.

\section{Elysia canguzua Er. Marcus, 1955}

(Fig. 13f)

\section{Synonyms}

Elysia eugeniae Ortea \& Espinosa 2002.

\section{Description}

Rhinophores short, blunt-tipped, same color and texture as head but with white patch at tip. Three siphonal openings in parapodial folds at head, middle, and posterior end. Dark to olive green on head and outer parapodia, mostly smooth with low sparse papillae. Body densely covered with distinctive red/orange spots, and smaller iridescent blue specks. Uneven rows of white spots on head and across sides of parapodia. Up to $12 \mathrm{~mm}$ long.

\section{Distribution}

Costa Rica, Brazil (Valdés et al., 2006; Camacho-García et al., 2014) and Panama (present study).

\section{Notes}

Found feeding on Bryopsis sp. growing on loose sediment 1-2 m depth. Preferred hosts reported to be both Bryopsis plumosa and Codium Stackhouse, 1797 (Jensen \& Clark, 1983). Parapodia typically held open when resting, adults do not swim when disturbed.

Elysia cornigera Nuttall, 1989

(Fig. 13g)

\section{Description}

Rhinophores long and curled, white to light green with red dots and many white papillae. White to grey on parapodia and head with numerous warty papillae. Red granules dotting head and rhinophores, smaller red dots scattered on parapodia. Densely enervated green digestive diverticula inside of parapodia. Up to $8 \mathrm{~mm}$ long. 


\section{Distribution}

Florida, Cuba, Cayman Islands, Bahamas (Valdés et al., 2006) and Panama (present study).

\section{Notes}

One small specimen found on coral rubble near Caulerpa racemosa, but only confirmed host is Acetabularia crenulata Lamouroux, 1816. Formerly synonymized with Elysia timida Risso, 1818, subsequently resurrected based on genetic, morphological, and developmental characteristics, and differences in photosynthetic ability (Krug et al., 2011, 2013). Upper surface of egg mass has flat ribbon of white to translucent ribbon of extra-zygotic yolk with granular appearance (Krug et al., in press).

\section{Elysia zuleicae Ortea \& Espinosa, 2002}

(Fig. 13h)

\section{Description}

External morphology quite variable. Rhinophores long and rolled. Narrow tail often extends a few millimeters beyond posterior end of parapodia, but some specimens have no tail. Parapodia are thin, sometimes with slight undulation but no siphonal openings. Body coloration typically olive to dark green. Head light to dark green, sometimes with rust-colored patches. Rhinophores colored white to brown-purple with scattered white papillae and white patches of pigment concentrated at tips. Outer surface of parapodia are green with scattered white specks and low white papillae. White papillae run along parapodial margin, sometimes forming crown-like clusters that appear to rise and fall along the margin. Some specimens, particularly juveniles, have a thin black line along parapodial margins surrounded by thicker white submarginal bands.

\section{Distribution}

Cuba, Costa Rica, Jamaica, Venezuela (Valdés et al., 2006; Caballer Gutiérrez et al., 2015) and Panama (present study).

\section{Notes}

Specializes on the green alga Udotea flabellum Howe, 1904. Juveniles hold parapodia flat against algal blade are distinctly darker green than adults. Adults swim readily by undulating parapodia when disturbed. Egg masses have a thin, white ribbon of extra-zygotic yolk.

\section{Elysia velutinus Pruvot-Fol, 1947}

(Fig. 13i)

\section{Description}

Parapodia form one small siphonal opening about halfway down the body. Body coloration varies from light to dark green, with spots or large patches of white or tan pigment. Head has large Y-shaped white to tan patch of pigment, starting anterior of pericardium and running up to the base of each rhinophore. Rhinophores are green at the base but distally become white or tan, sometimes with small papillae. Panamanian specimens tend to have less white pigmentation/fewer papillae on external surface of parapodia compared with those found in the Bahamas. Up to $15 \mathrm{~mm}$ long.

\section{Distribution}

Florida, Mexico, Honduras, Costa Rica, Panama, Colombia, Venezuela, Bermuda, Bahamas, Curaçao, Cayman Islands, Jamaica, Puerto Rico, Virgin Islands, St. Maarten/St. Martin, St. Lucia, Barbados, St. Vincent and the Grenadines, Grenada, Brazil (Valdés et al., 2006; Malaquias, 2014; Caballer Gutiérrez et al., 2015).

\section{Notes}

Typically associated with Halimeda spp., most commonly the upright branching species $H$. incrassata J.V. Lamouroux, 1816 and H. monile J.V. Lamouroux, 1816. Parapodia held together when resting, slugs do not swim when disturbed. Egg masses have continuous ribbon of bright yellow extra-zygotic yolk. This species was previously known as Elysia tuca Ev. Marcus \& Er. Marcus, 1967 but Krug et al. (in press) found that Elysia velutinus is a senior synonym.

Elysia marcusi Ev. Marcus, 1972

(Fig. 13j)

\section{Description}

Small bodied. Parapodia fused to body with fusion line visible running dorsally down the body. Uniformly light to dark green, sometimes with white patches. Rhinophores solid white, simple, flat (not rolled), and fully retractable into head. Up to $5 \mathrm{~mm}$ long.

\section{Distribution}

Florida, Costa Rica, Bahamas, Jamaica (Valdés et al., 2006) and Panama (present study).

\section{Notes}

Found on mixed collection of Caulerpa racemosa and Halimeda sp., but preferred host is Halimeda opuntia (Krug et al., in press). Resting slugs flatten into perfectly round circles, superficially resembling Bosellia mimetica Trinchese, 1891. Crawling slugs elongate into form more typical of Elysia spp.

\section{Discussion}

Few studies of heterobranch sea slugs have reported collecting effort. In the Eastern Pacific, Nybakken (1978) 
searched for sea slugs for $120 \mathrm{~h}$ and found 31 species in a California intertidal assemblage. Hermosillo (2006) searched for $750 \mathrm{~h}$ and found 140 species in Bahía de Banderas, Pacific coast of Mexico, while Bertsch (2008) in Bahía de Los Ángeles, Pacific coast of Mexico found 81 species in $229.3 \mathrm{~h}$ of searching. For the Caribbean, Thompson (1976) reported a total of 61 species for a searching time of approximately $298 \mathrm{~h}$, mostly in Jamaica. A recent study conducted in a Mexican Caribbean coral reef reported 32 species observed in a total of 74.4 h of search (Sanvicente-Añorve et al., 2012), however in this case indirect methods were also included. The preceding studies also found that the highest number of species belonged to the clade Nudibranchia, which is consistent with the greater overall diversity in this group (Gosliner et al. 2015).

Based on the information provided in these prior studies, the collecting effort of our study (307.5 h) represents one of the highest recorded for sea slugs not only in the Caribbean but also in tropical regions. Despite this large collecting effort, relatively few species were found compared to the total known diversity in the Caribbean. Only 82 out of the 308 species reported by Valdés et al. (2006) or the 329 species reported by García \& Bertsch (2009) were found; this represents about $25 \%$ of known Caribbean species diversity. All the species reported here were included in Valdés et al. (2006) except for those that could not be identified at the species level. From the 19 species recorded by Collin et al. (2005) five were not observed during the newly conducted field work in Panama: Atys macandrewii E. A. Smith, 1872, Elysia flava Verrill, 1901, Aphelodoris antillensis Bergh, 1879, Paradoris adamsae Padula \& Valdés, 2012 [as Paradoris mulciber (Ev. Marcus, 1971)] (see Padula \& Valdés, 2012) and Doto cf. caramella Er. Marcus, 1957.

The total diversity of sea slugs documented in this study, as well as the total diversity in the Caribbean region is much lower than in the Indo-Pacific region, which is the center of tropical diversity. For example, Gosliner et al. (2015) reported 815 sea slug species just in the region of Anilao, located in the Philippine Islands. The total diversity in other Indo-Pacific regions increases dramatically from peripheral areas such as Tanzania (258 spp.), Guam (474 spp.) or French Polynesia (504 spp.) to the Coral Triangle where according to Gosliner et al. (2015) diversity reaches unprecedented levels (Philippines 1006 spp., Papua New Guinea 646 spp.). Unfortunately, there are no sea slug diversity studies in the Indo-Pacific region documenting collecting effort and therefore comparisons with the present study are not possible.

For heterobranch sea slugs the experience of the observers in finding species while conducting surveys/inventories is critical, as these animals are difficult to find.
Many sea slugs are very small and well-camouflaged, making them nearly invisible to the untrained eye. Even experienced observers often have difficulties finding species in the Caribbean because the abundances of sea slugs in this region are typically lower than in other tropical regions of the world (Valdés et al., 2006). Our results are consistent with this observation, as the total number of specimens found was relatively low and many species were only represented by one specimen.

Most of the sacoglossan species were found by indirect methods. Individuals of these species are very small and remarkably cryptic on their host algae. In spite of this, a few species were found by direct observations (e.g. Elysia crispata and Polybranchia viridis), primarily due to their more conspicuous size and tendency to periodically leave their algal food sources. Elysia crispata is particularly common in the area and throughout the Caribbean (Collin et al., 2005; Valdés et al., 2006). In contrast, most species belonging to other clades (Table 1) were found by direct methods due to their (mostly) larger size and more observer experience finding these groups, especially nudibranchs.

This paper represents a substantial increase in the knowledge of heterobranch sea slug diversity in Bocas del Toro, Panama as compared to the single previous publication from Collin et al. (2005). This increase in known diversity strongly suggests that the distribution of species within the Caribbean is still poorly known (at least in regards to some localities), and thus species ranges may need to be modified as more surveys are conducted.

\section{Abbreviation}

STRI, Smithsonian Tropical Research Institute

\section{Acknowledgements}

The course "Taxonomy and Biology of Sea slugs" was funded by awards from the US National Science Foundation DEB-1355190 to PJK and DEB-1355177 to

$A V$, and organized by Rachel Collin of the Smithsonian Tropical Research Institute in Bocas del Toro. The two NSF grants also supported the travel of several students (JM, SM, JD, JA and postdoc RE). Other funding agencies made travel possible for other student participants: JAG (Conchologists of America and the University of Maryland Biological Sciences Department Genie Clark Research Award), JD and JA (CSULA Culminating project fund), XGV and KG (STRI fellowships), HG (Fundação de Amparo à Pesquisa do Estado de São Paulo, FAPESP 2014/06979-1), LJ (International Affairs Office of the Universidad de Antioquia) and VB (British Ecological Society, travel grant 5585-6629, and Bombay Natural History Society).

Several staff members of the Smithsonian Tropical Research Institute in Bocas del Toro were extremely helpful supporting the fieldwork and course activities, these are: Plinio Gondola, Urania Gonzalez, Tanyusha Grenald, Arcadio Castillo, Deyvis Gonzalez and Nerea Nieto.

Collecting of some specimens was possible with permits ARAP 27 (2015) and ANAM SE/A-64-15 issued by the Panamanian Government.

\section{Sources of funding}

US National Science Foundation, Conchologists of America, University of Maryland, California State University Los Angeles, Smithsonian Tropical

Research Institute, Fundação de Amparo à Pesquisa do Estado de São Paulo, International Affairs Office of the Universidad de Antioquia, British Ecological Society, Bombay Natural History Society. 
Funding bodies did not participate in the design of the study, data collection, analysis, and interpretation or in writing the manuscript.

\section{Authors' contributions}

JAG, RAE, XGV, HCGF, JBM, SMM, VJB, KGM, LMJ, GL, CAH, JDA, JMD, WG, PJK, AV conceived the study, conducted the surveys, identified the specimens, wrote the manuscript. PJK, AV photographed the specimens. SMM, JDA, JMD, RAE, PJK described the egg masses. All authors read and approved the final manuscript.

\section{Competing interests}

The authors declare that they have no competing interests.

\section{Data reproduction}

All data relevant to this study is reproduced within the paper.

\section{Author details}

1 Laboratory of Molecular Evolution, Center for Bioinformatics and Computational Biology, University of Maryland, College Park, MD 20742, USA. ${ }^{2}$ NMFS, National Systematics Laboratory, National Museum of Natural History, Smithsonian Institution, MRC-153, PO Box 37012, Washington, DC 20013, USA. ${ }^{3}$ Department of Biological Sciences, California State University, Los Angeles, CA 90032-8201, USA. ${ }^{4}$ Colección Nacional de Moluscos, Instituto de Biología, Universidad Nacional Autónoma de México, Tercer Circuito Exterior s/n, 70-153, 04510 México, D.F., Mexico. ${ }^{5}$ Museu de Zoologia da Universidade de São Paulo, São Paulo Caixa Postal 42494, 042999-970, SP, Brazil. ${ }^{6}$ Department of Biological Sciences, California State Polytechnic University, 3801 West Temple Avenue, Pomona, CA 91768, USA. ${ }^{7}$ Bombay Natural History Society, Hornbill House, Shaheed Bhagat Singh Road, Mumbai 400 001, Maharashtra, India. ${ }^{8}$ Escuela de Biología, Universidad de Costa Rica, San Pedro 11501-2060, San José, Costa Rica. ${ }^{9}$ Grupo de Limnología Básica y Experimental y Biología y Taxonomía Marina (LimnoBasE y Biotamar), Instituto de Biología, Facultad de Ciencias Exactas y Naturales, Universidad de Antioquia, A.A. 1226, Medellín 05001000, Colombia. ${ }^{10}$ Departamento de Biología, Facultad de Ciencias Naturales y Matemáticas, Universidad de El Salvador, San Salvador, El Salvador. ${ }^{11}$ Instituto de Ciencias Marinas y Limnología, Facultad de Ciencias Naturales y Matemáticas, Universidad de El Salvador, Ciudad Universitaria, San Salvador, El Salvador. ${ }^{12}$ Department of Integrative Biology, University of South Florida, 4202 East Fowler Avenue, Tampa, FL 33620, USA.

\section{Received: 11 May 2016 Accepted: 3 June 2016}

Published online: 15 July 2016

\section{References}

Alexander J, Valdés A. The ring doesn't mean a thing: Molecular data suggest a new taxonomy for two Pacific species of sea hares (Mollusca: Opisthobranchia, Aplysiidae). Pac Sci. 2013;67:283-94.

Alvim J, Pimenta AD. Taxonomic review of the family Discodorididae (Mollusca: Gastropoda: Nudibranchia) from Brazil, with descriptions of two new species. Zootaxa. 2013;3745(2):152-98

Belmonte T, Alvim J, Padula V, Muricy G. Spongivory by nudibranchs on the coast of Rio de Janeiro state, southeastern Brazil. Spixiana. 2015:38:187-95.

Bertsch H. Anatomy and zoogeography of Glossodoris sedna and Chromodoris grahami (Opisthobranchia: Nudibranchia) in the Tropical Western Atlantic and Caribbean. Veliger. 1988;30:395-9.

Bertsch H. Capítulo 11: Opistobranquios. In: Danemann GD, Excurra E, editors. Bahía de los Ángeles: Recursos Naturales y Comunidad. Línea base 2007. Mexico City: Secretaría de Medio Ambiente y Recursos Naturales (SEMARNAT); 2008. p. 319-38.

Caballer M, Ortea J. The genus Hermaea Lovén, 1844 (Mollusca: Sacoglossa) in the Caribbean, with the description of a new species from Cuba. Rev Acad Canaria Cienc. 2013:25:67-78.

Caballer Gutiérrez M, Ortea JA, Rivero N, Tucker GC, Malaquias MAE, Narciso S. The opisthobranch gastropods (Mollusca: Heterobranchia) from Venezuela: An annotated and illustrated inventory of species. Zootaxa. 2015;4034:201-56.

Camacho-García Y, Pola M, Carmona L, Padula V, Villani G, Cervera L. Diversity and distribution of the heterobranch sea slug fauna on the Caribbean of Costa Rica. Cah Biol Mar. 2014;55:109-27.

Capper A, Paul VJ. Grazer interactions with four species of Lyngbya in southeast Florida. Harmful Algae. 2008;7:717-28.
Carmona L, Pola M, Gosliner TM, Cervera JL. A tale that morphology fails to tell: A molecular phylogeny of Aeolidiidae (Aeolidida, Nudibranchia, Gastropoda). PLoS One. 2013;8:e63000.

Carmona L., Bhave V., Salunkhe R., Pola M., Gosliner T.M. and Cervera J.L. (2014a) Systematic review of Antaeolidiella (Mollusca, Nudibranchia, Aeolidiidae) based on morphological and molecular data, with a description of three new species. Zoological Journal of the Linnean Society 171, 108-132.

Carmona L., Pola M., Gosliner T.M. and Cervera J.L. (2014b) The Atlantic-Mediterranean genus Berghia Trinchese, 1877 (Nudibranchia: Aeolidiidae): taxonomic review and phylogenetic analysis. Journal of Molluscan Studies 80, 482-498.

Christa G, Goul SB, Franken J, Vleugels M, Karmeinski D, Händeler K, et al. Functional kleptoplasty in a limapontioidean genus: phylogeny, food preferences and photosynthesis in Costasiella, with a focus on C. ocellifera (Gastropoda: Sacoglossa). J Molluscan Stud. 2014;80:499-507.

Clark KB, DeFreese D. Population ecology of Caribbean Ascoglossa (Mollusca, Opisthobranchia) - a study of specialized algal herbivores. Am Malacological Bull. 1987:5:259-80.

Collin R. Ecological Monitoring and Biodiversity Surveys at the Smithsonian Tropical Research Institute's Bocas del Toro Research Station. Caribb J Sci. 2005;41(3):367-73.

Collin R, Díaz MC, Norenburg J, Rocha RM, Sánchez JA, Schulze A, et al. Photographic identification guide to some common marine invertebrates of Bocas Del Toro, Panama. Caribb J Sci. 2005;41:638-707.

Crescini R, Villalba W, De Sisto M. Primer registro de Doto chica (Mollusca: Dotidae) en Venezuela. First record of Doto chica (Mollusca: Dotidae) in Venezuela. Rev Mex Biodiversidad. 2013:84:668-70.

Cronin G, Hay ME, Fenical W, Lindquist N. Distribution, density, and sequestration of host chemical defenses by the specialist nudibranch Tritonia hamnerorum found at high densities on the sea fan Gorgonia ventalina. Mar Ecol Prog Ser. 1995;119:177-89.

Curtis NE, Massey SE, Pierce SK. The symbiotic chloroplasts in the sacoglossan Elysia clarki are from several algal species. Invertebr Biol. 2006;125:336-45.

Curtis NE, Massey SE, Schwartz JA, Tagihof H, Pierce SK. The intracellular, functional chloroplasts in adult Elysia crispata come from several algal species, and are different from those in juvenile slugs. Integr Comp Biol. 2004;44:686.

Edmunds M. Opisthobranchiate Mollusca from Ghana: Chromodorididae. Zool J Linnean Soc. 1981;72:175-201.

Galvão Filho HC, Araujo AK, Silva FV, Azevedo VMD, Meirelles CAO, MatthewsCascon H. Sea slugs (Gastropoda: Heterobranchia) from a poorly known area in North-east Brazil: Filling gaps in Atlantic distributions. Mar Biodivers Rec. 2015:8:e115.

García FJ, Bertsch H. Diversity and distribution of the Gastropoda Opisthobranchia from the Atlantic Ocean: A global biogeographic approach. Sci Marina. 2009:73:153-60.

García-García FJ, Domínguez M, Troncoso JS. Opistobranquios de Brasil: descripción y distribución de opistobranquios del litoral de Brasil y del Archipiélago Fernando de Noronha. Vigo: Feito, S.L; 2008.

Gonzalez L, Hanson D, Valdés A. Molecular divergence between two sympatric species of Dondice (Mollusca: Nudibranchia) with distinct feeding specializations. J Mar Biol Assoc U K. 2013;93:1887-93.

Goodheart J, Camacho-García Y, Padula V, Schrödl M, Cervera JL, Gosliner TM, et al. Systematics and biogeography of Pleurobranchus Cuvier, 1804, sea slugs (Heterobranchia: Nudipleura: Pleurobranchidae). Zool J Linn Soc. 2015;174:322-62

Gordon B. A Panama forest and shore: natural history and Amerindian culture in Bocas del Toro. Pacific Grove: Boxwood Press; 1982.

Gosliner TM, Valdés A, Behrens DW. Nudibranch and sea slug identification: Indo-Pacific. Jacksonville: New World Publications; 2015.

Grzymbowski Y, Stemmer K, Wägele H. On a new Ercolania Trinchese, 1872 (Opisthobranchia, Sacoglossa, Limapontiidae) living within Boergesenia Feldmann, 1950 (Cladophorales), with notes on anatomy, histology and biology. Zootaxa. 2007;1577:3-16.

Hermosillo A. Ecología de los opistobranquios (Mollusca) de Bahía de Banderas, Jalisco-Nayarit, México. Ph.D. Dissertation: Universidad de Guadalajara; 2006. 151.

Jensen K, Clark KN. Annotated checklist of Florida ascoglossan Opisthobranchia. Nautilus. 1983;97:1-13.

Jensen KR, Krug PJ, Dupont A, Nishina M. A review of taxonomy and phylogenetic relationships in the genus Costasiella (Heterobranchia: Sacoglossa), with a description of a new species. J Molluscan Stud. 2014;80:562-74. 
Johnson RF, Gosliner TM. Traditional taxonomic groupings mask evolutionary history: A molecular phylogeny and new classification of the chromodorid nudibranchs. PLoS One. 2012;7:e33479.

Krug PJ, Händeler K, Vendetti J. Genes, morphology, development and photosynthetic ability support the resurrection of Elysia cornigera (Heterobranchia : Plakobranchoidea) as distinct from the 'solar-powered' sea slug, E. timida. Invertebr Syst. 2011;25:477-89.

Krug P.J.,Vandetti J.E., and Valdés A. In press. Molecular and morphological systematics of Elysia Risso, 1818 (Heterobranchia: Sacoglossa) from the Caribbean region. Zootaxa.

Krug PJ, Vendetti JE, Rodriguez AK, Retana JN, Hirano YM, Trowbridge CD. Integrative species delimitation in photosynthetic sea slugs reveals twenty candidate species in three nominal taxa studied for drug discovery, plastid symbiosis or biological control. Mol Phylogenet Evol. 2013;69:1101-19.

Krug PJ, Vandetti JE, Ellingson RA, Trowbridge CD, Hirano YM, Trathen DY, et al. Species selection favors dispersive life histories in sea slugs, but higher peroffspring investment drives shifts to short-lived larvae. Syst Biol. 2015;64:983-99.

Lovelock CE, Feller IC, McKee KL, Engelbrecht BM, Ball MC. The effect of nutrient enrichment on growth, photosynthesis and hydraulic conductance of dwarf mangroves in Panama. Funct Ecol. 2004;18:25-33.

Malaquias MAE. New data on the heterobranch gastropods ('opisthobranchs') for the Bahamas (tropical western Atlantic Ocean). Mar Biodivers Rec. 2014;7:e27.

Mariño J, Farfán E, Caballer M. Primer registro de Dondice parquerensis (Mollusca: Favorinidae) para Venezuela. Rev Mex Biodiversidad. 2011;82:709-12.

Marcus E. On some opisthobranchs from Florida. Bull Mar Sci. 1972;22:284-308.

Marcus E, Marcus E. American opisthobranch mollusks. Stud Trop Oceanography. 1967;6:1-256

McDonald GR, Nybakken JW. List of the worldwide food habits of nudibranchs. Veliger. 1997:40:157-9.

McDonald GR, Nybakken JW. A worldwide review of the food of nudibranch mollusks. II. The suborder Dendronotacea. Veliger. 1999;42:62-6.

Middlebrooks ML, Bell SS, Curtis NE, Pierce SK. Atypical plant-herbivore association of algal food and a kleptoplastic sea slug (Elysia clarki) revealed by DNA barcoding and field surveys. Mar Biol. 2014;161:1429-40.

Moretzsohn F, Brenner J, Michaud P, Tunnell JW, Shirley T. Biodiversity of the Gulf of Mexico Database (BioGoMx). Version 1.0. Corpus Christi: Harte Research Institute for Gulf of Mexico Studies, Texas A\&M University-Corpus Christi; 2011.

Nybakken JW. Abundance, diversity and temporal variability in a California intertidal nudibranch assemblage. Mar Biol. 1978;45:129-46.

Ornelas-Gatdula E, DuPont A, Valdés A. The tail tells the tale: taxonomy and biogeography of some Atlantic Chelidonura (Gastropoda: Cephalaspidea: Aglajidae) inferred from nuclear and mitochondrial gene data. Zool J Linn Soc. 2011;163:1077-95.

Ornelas-Gatdula E, Camacho-García Y, Schrödl M, Padula V, Hooker Y, Gosliner TM, et al. Molecular systematics of the 'Navanax aenigmaticus' species complex (Mollusca, Cephalaspidea): coming full circle. Zool Scr. 2012;41:374-85.

Ortea J, Espinosa J, Buske Y, Caballer M. Additions to the inventory of the sea slugs (Opisthobranchia and Sacoglossa) from Guadeloupe (Lesser Antilles, Caribbean Sea). Rev Acad Canaria Cienc. 2013;25:163-94.

Ortea J, Valdés A, Espinosa J. North Atlantic nudibranchs of the Chromodoris clenchi colour group (Opisthobranchia: Chromodorididae). J Molluscan Stud. 1994;60:237-48.

Padilla-Verdín CJ, Carballo JL, Camacho ML. A qualitative assessment of spongefeeding organisms from the Mexican Pacific Coast. Open Mar Biol J. 2010;4:39-46.

Padula V, Valdés A. Phylogeny and biogeography of Paradoris (Nudibranchia, Discodorididae), with the description of a new species from the Caribbean Sea. Veliger. 2012;51:165-76.

Padula V, Bahia J, Correia MD, Sovierzoski HH. New records of opisthobranchs (Mollusca: Gastropoda) from Alagoas, Northeastern Brazil. Mar Biodivers Rec. 2012;5:e57.

Pierce SK, Massey SE, Hanten JJ, Curtis NE. Horizontal transfer of functional nuclear genes between multicellular organisms. Biol Bull. 2003;204:237-40.

Redfern C. Bahamian Seashells: A thousand species from Abaco. Boca Raton: Bahamas. BahamianSeashells.com, Inc.; 2001.

Rodríguez E, Almanza R, Alvarado R. Situación bíofísica y ambiental de la Provincia de Bocas del Toro. In: Heckadon S, editor. Agenda Ecológica y Social para Bocas del Toro. Panama: Impresora Continental; 1993. p. 55-72.

Sanvicente-Añorve L, Hermoso-Salazar M, Ortigosa J, Solís-Weiss V, Lemus-Santana E. Opisthobranch assemblages from a coral reef system: the role of habitat type and food availability. Bull Mar Sci. 2012;88(4):1061-74.
Thompson TE. Hunting for nudibranchs in the Caribbean Sea. J Molluscan Stud. 1976;42:451-6.

Valdés A, Ortea J. Review of the genus Doriopsilla Bergh, 1880 (Gastropoda: Nudibranchia) in the Atlantic Ocean. Veliger. 1997:40:240-54.

Valdés A, Hamann J. Two new species of Doriopsilla from the tropical Western Atlantic with remarks on Cariopsillidae Ortea \& Espinosa, 2005. Veliger. 2008:50:210-8.

Valdés A, Hamann J, Behrens DW, DuPont A. Caribbean Sea Slugs: A field guide to the opisthobranch mollusks from the tropical northwestern Atlantic. Gig Harbor: Sea Challengers Natural History Books; 2006.

Valdés A, Alexander J, Crocetta F, Yokes MB, Giacobbe S, Poursanidis D, et al. The origin and dispersal pathway of the spotted sea hare Aplysia dactylomela (Mollusca: Opisthobranchia) in the Mediterranean Sea. Aquat Invasion. 2013;8:427-36.

Valdés A, Gatdula U, Sheridan N, Herrera J. Multi-data set revision of two uncommon species of Chromodorididae (Nudibranchia) from the Gulf of Mexico. Am Malacological Bull. 2011;29:51-62.

Willan RC. A review of diets in the Notaspidea (Mollusca: Opisthobranchia). J Malacological Soc Aust. 1984;6:125-42.

Wysor B, Kooistra WH. An annotated list of marine Chlorophyta from the Caribbean coast of the Republic of Panama. Nova Hedwigia. 2003;77(3-4):487-523.

\section{Submit your next manuscript to BioMed Central and we will help you at every step:}

- We accept pre-submission inquiries

- Our selector tool helps you to find the most relevant journal

- We provide round the clock customer support

- Convenient online submission

- Thorough peer review

- Inclusion in PubMed and all major indexing services

- Maximum visibility for your research

Submit your manuscript at www.biomedcentral.com/submit
C Biomed Central 